NBER WORKING PAPER SERIES

\title{
IMPLICATIONS OF THE ILLINOIS REEMPLOYMENT BONUS EXPERIMENTS \\ FOR THEORIES OF UNEMPLOYMENT AND POLICY DESIGN
}

Bruce D. Meyer

Working Paper No, 2783

NATIONAL BUREAU OF ECONOMIC RESEARCH

1050 Massachusetts Avenue

Cambridge, MA 02138

December 1988

I would like to thank Bo Honore, Dale Mortensen, and Paula Worthington for many useful discussions, and seminar participants at the NBER, Northwestern, and Princeton for their comments. Julie Ho provided excellent research assistance. This paper was written while the author was visiting the Industrial Relations Section, Princeton University. This research is part of NBER's research program in Labor Studies. Any opinions expressed are those of the author not those of the National Bureau of Economic Research. 
NBER Working Paper \#2783

December 1988

\section{IMPLICATIONS OF THE ILLINOIS REEMPLOYMENT BONUS EXPERIMENTS FOR THEORIES OF UNEMPLOYMENT AND POLICY DESTGN}

\section{ABSTRACT}

Reemployment bonus experiments offer large lump sum payments to unemployment insurance (UI) recipients who find a job quickly. Such experiments are underway or have been recently completed in four states. This paper analyzes the results from Illinois and discusses the implications of the experiments for theories of unemployment and policy design. I examine the hazard rate of exit from unemployment and find that it is significantly higher for the experimental groups, but only during the period of bonus eligibility. Both labor supply and search theories of unemployment are shown to suggest. a $r$ ise in the reemployment hazard just before the end of bonus eligibilicy and to suggest larger effects of the fixed amount bonus for lower income gloups. Only weak support is found for these hypotheses, which suggests limitations of the models of unemployment. Some modifications of the models are suggested.

The experiments demonstrate the effects of economic incentives on job finding behavior but they do not show the desirability of a permanent reemployment bonus program. Evidence from another sample suggests that as many as half of those who received a reemployment bonus returned to their previous employer, so that a bonus program that pays people returning to their last employer would provide a strong encouragement to temporary layoffs. A discussion of UI claim filing behavior suggests that a permanent program could well increase the frequency or promptness of filing, thus reducing any financial advantages of a bonus program.

Bruce D. Meyer

Northwestern University

Department of Economics

2003 Sheridan Road

Evanston, IL 60201 


\section{Introduction}

Reemployment bonus experiments are a new type of social experiment designed to find cost effective ways of shortening unemployment spells. These experiments offer large lump sum payments to people who have filed for unemployment insurance (UI) if they find a job within a specified period of time. The first experiments were conducted in Illinois, and three others are underway or have been recently completed. ${ }^{1}$ This paper analyzes the results of the Illinois experiments and discusses their implications for theories of unemployment and policy design.

In the Illinois experiments, randomly assigned UI recipients were eligible for a large monetary bonus if they returned to work with either thei: old employer of a new employer within 12 weeks. The results of the experiments were striking; the mean spell of UI receipt was significantly reduced by the bonus to employees. Even after subtracting the cost of the bonuses, the state UI office appears to have saved money by shortening unemployment spelis. Surprisingly, the shorter spells of those eligible for bonus payments do not appear to have come at the expense of lower quarterly earnings after finding a job. The strength of these results and the possibility that they may affect UI policy ${ }^{2}$ indicate that the experiments merit a closer examination. This paper mostly discusses the results of the

${ }^{1}$ Further experiments are in progress or have been recently completed in New Jersey, Pennsylvania, and Washington. The experiments in New Jersey and Pennsylvania provide job finding services to some participants as well as bonus payments. These services include job search assistaice, training, relocation assistance and other services. Experiments which will provide funds for self-employment are also planned.

2 The Department of Labor is currently funding these experiments. As stated in U.S. Department of Labor (1988) "[t]he goal is to find innovative, cost-effective ways to reduce structural unemployment, increase economic activity, and speed up the return of unemployed workers to productive jobs." 
Illinois experiments, although the experimental design and some of the results of the other experiments are mentioned.

The reemployment hazards for the control and experimental groups are analyzed using parametric and nonparametric techniques. The reemployment hazard rate for those eligible for the bonus is found to be significantly higher than the hazard for the Control Group, and this pattern is evident onl: during the period of eligibility for the reemployment bonus. However, the job finding rate is not found to rise appreciably just before the end of the period of bonus eligibility. A rise would be predicted by most labor supply and search theories of unemployment.

The empirical findings of the paper have additional implications for theories of unemployment. Low income individuals, which are predicted by labor supply and search theories of unemployment to respond more to the fixed bonus amount, do not reduce their unemployment spells by more than high income individuals. Contrary to some search models, reemployment earnings do not fall for the experimental groups even though they find jobs more quickly.

Difficulties with extrapolating the experimental results to a permanent reemployment bonus program are emphasized in the later parts of the paper. In a sample similar to the Illinois experiment sample, it is found that about half of those that would qualify for a bonus returned to their previous employer. This suggests that a reemployment bonus program would subsidize temporary layoffs by firms. Furthermore, the timing of the bonus offer can lead to strong incentives for individuals to prolong unemployment or to file for UI when it would not otherwise be worthwile. Either outcome would greatly reduce the desirability of a bonus program. Other difficulties with a bonus program such as displacement effects are also discussed. 
The next two sections set the stage for the remainder of the paper. Section 2 summarizes the design of the Illinois experiments and their results, while Section 3 describes theories of unemployment that give predictions about the effects of a reemployment bonus. The hazard rate of exit from the UI rolls is examined nonparametrically and then parametrically with controls for other variables in Section 4. Section 5 examines the effects of the experiments on different income groups. To check the validity of the experiments, Section 6 considers the possibility that the results are spurious Hawthorne or placebo effects. Some implizations of the experiments for labor supply and search theories of unemployment are discussed in Section 7 . Section 8 discusses problems with extrapolating the experimental results to a permanent reemployment bonus program. Section 9 offers some closing comments and conclusions.

\section{A Summary of the Illinois Experiments and Their Results}

The Illinois experiments were directed by Robert Spiegelman and Steven Woodbury of the Upjohn Institute and a complete description of the experiments and an excellent summary of the results can be found in Spiegelman and Woodbury (1987) and Woodbury and Spiegelman (1987). The Illinois experiments assigned those in the eligible population to one of three groups on the basis of the last two digits of their Social Security number. I will call the chree groups the Control Group, Ciaimant Experiment, and Employer Experiment. The Claimant Experiment gave a $\$ 500$ bonus to individuals who found a job in less than 11 weeks after filing for UI and who held that job for at least 4 month. The Employer Experiment gave a $\$ 500$ bonus to employers who hired an individual 
Iess than 11 weeks after the individual filed for UI and who employed the individual for at least 4 months afterwards. ${ }^{3}$

The eligible population that was randomly assigned to one of the three groups consisted of those who satisfied three requirements. First, they had to file a monetarily eligible initial claim (i.e. they hi: to satisfy base period earnings requírements, and not file a transitional, additional or reopened claim) for UI between July 29, 1984 and November 17, 1984. Such people were eligible for 26 weeks of state regular benefits and up to 12 additional weeks of Federal Supplemental Compensation benefits. ${ }^{4}$ Second, they had to register with one of 22 Job service offices in Northern and Central IlIinois. These 22 included about half of the offices in the area. In Illinois and many other states the unemployment insurance offices and the employment or job service offices aze separate entities. Two important groups are exempted from the requirement of going to the Job Service as part of the search effort required to receive $U^{-}$. Individuals who are members of unions that allocate jobs through a hiring hall and individuals with a definite recall date within 4 weeks are excluded from the Job Service requirement. Third, they had to be between ages 20 and 54 . The 17,306 people satisfying these three requirements were randomly assigned to one of three groups.

A fourth requirement (and apparently a reconfirmation that the first and third requirements above were satisfied) further reduced the sample to $12,101$. The final requirement was that claimants had to be nonmonetarily eligible

3 In both experiments, the individual had to be employed for at least 30 hours per week.

${ }^{4}$ It was possible for a person to receive UI benefits over more than 38 weeks in a benefit year if he or she received partial UI during periods of part time work. 
(i.e. not have quit or been fired by their last employer, and have satisfied availability for work requirements), and the state UI office had to be able to locate their records. These screens left approximately 4,000 people in each of the three groups: the Control Group, the Claimant Experiment and the Employer Experiment. The randomness of the assignment of individuals to the groups is supported by comparisons of the mean values of many attributes of the groups reported in Woodbury and Spiegelman (1987).

Individuals who were assigned to either the Claimant Experiment or the Employer Experiment were interviewed by a Job Service employee who explained the bonus for which they were potentially eligible. These individuals were further asked to sign an agreement to participate in the experiment. 84 percent of those assigned to the Claimant Experiment signed the agreement, but only 65 percent of those in the Employer Experiment signed.

The data source for the empirical work on the experiments is the PublicUse Data File documented in woodbury et al. (1987). This data set contains demographic variables, quarterly earnings, measures of the amount and timing of UI benefit receipt, and some demographic information. However, only the variables that were used in the American Economic Review paper by Woodbury and Spiegelman (1987) are included. Information on recall to previous jobs, and industry or occupation are unavailable.

Most of the analysis in the paper will center on the Claimant Experiment in which the bonus was paid to UI recipients. There are several reasons for this emphasis. The experiments in other states tend to follow the pattern of the Claimant Experiment, so it seem likely that any permanent program would take this form. The Claimant Experiment is a less complicated treatment than the Employer Experiment since the employer's cooperation is less important. 
Thus, the Claimant Experiment results are likely to be more pronounced; which makes their examination easier and less likely to be inconclusive because of sampling error.

Table 1 displays some of the major findings of the experiments. These Eindings were previously discussed in Woodbury and Spiegelman (1987). The results indicate a strong effect of economic incentives on job finding behavior. The measures of unemployment are always weeks of UI benefits received. The mean number of weeks of compensated unemployment are lower for both the Claimant Experiment and the Employer Experiment compared with the Control Group. Table 1 reports numbers for both the first spell of unemployment and the benefit year (the 52 weeks following the claim date). Those assigned to the Claimant Experiment had 1.37 fewer weeks of unemployment than the Control Group in the first spell and 1.15 fewer weeks in the benefit year. Both of these numbers are significantly different from zero in tests with conventional sizes. The differences between those in the Employer Experiment and the Control Group are much smaller; .67 weeks in the first spell on average and .36 weeks in the benefit year. Only the first spell difference is significantly differert from zero at the .05 level. One should note that the means being compared are averages over the entire population assigned to each of the three groups, not only those that agreed to participate. Therefore, selection bias is not an issue in these comparisons

Line (3) of Table 1 indicates that the reductions in weeks of compensated unemployment corresponded to large reductions in mean dollars of UI benefits paid. Even after accounting for the $\$ 500$ bonuses paid which are reported in line (5), both the Claimant and Employer Experiments appear to have reduced government expenditures. 
Even more surprisingly, the reduced length of unemployment does not appear to have been achieved at the cost of lower earnings by UI recipients. Tables 2 and 3 report a variety of earnings measures. Lines ( 8 ) and (9) of Table 2 indicate that the differences between the Control Group and either of the experimental groups in terms of mean quarterly earnings after the end of the first unemployment spell are not significantly different from zero. The point estimates of the reemployment earnings measures are in fact higher for the Claimant Experiment than the Control Group. The reemployment earnings measures are calculated using only individuals whose spells concluded before the relevant quarter

Because of the presence of several very large earnings observations, median and trimmed mean earnings are reported in Table 3 . The earnings measures reported in lines (1) through (7) of Table 3 are for the subsainfle of positive observations. A significant fraction of individuals have no reported post-UI earnings. The different earnings measures give similar conclusions even though the measures are estimated using different samples. 5

\section{Theoretical Effects of the Bonus Offer}

This section describes labor supply and search theories of unemployment and how they provide an analytical framework in which the bonus experiments can be examined. The short run effects of the experiments are discussed here: it is assumed that the experiments did not affect layoff or recall behavior of

${ }^{5}$ If one is concerned that the bonus offer may have reduced migration out of Illinois, then using all observations (including zeros) would bias upward the Claimant Experiment post-UI earnings. Measures conditional on positive earnings (such as most of those in Table 3 ) would not be subject to this source of bias. 
firms or the propensity of individuals to file for UI benefits. This assumption seens reasonable given that the experiments only lasted 17 weeks and were not widely publicized, so that firms likely did not make long term adjustments to the program. The long run effects of adopting a permanent reemployment bonus program are discussed towards the end of this paper.

Labor supply theories such as Moffitt and Nicholson (1982) model unemployment in a static labor-leisure choice framework. An individual's utility is an increasing function of income and unemployment, where unemployment is valued because of $i=s$ leisure component. An individual can become reemployed at any time and search behavior does not affect the reemployment wage. The maximization is done subject to a budget constraint that is altered by UI. The period over which this constrained maximization takes place is moderately long, such as a year.

The incentives of the Illinois bonus experiments can be analyzed in this framework. Assume that any leisure during the period must be taken in the first spell of unemployment. The Claimant Experiment then raises by $\$ 500$ the budget constraint of any person who chooses II weeks or less of unemployment. Figure 1 displays the original and modified budget constraint created by the bonus program. The change in the budget constraint has different effects depending on a person's location on the original budget constraint. The effect of the bonus on the combined popularion is uncertain. If initially a person was unemployed for 11 weeks or less, then the income effect will cause them to lengthen their unemployment spel1.

On the other hand, if a person was originally unemployed for more than li weeks, there is an incentive to reduce the unemployment spell to 11 or less weeks. Because of the discontinuity in the budget set at 11 weeks, many 
people will maximize their utility by receiving exactly 10 weeks of UI. ${ }^{6}$ One must argue informally, as Moffit and Nicholoson do in their paper, that the random nature of job finding leads people to cluster around this discontinuity point. This modification would lead to the prediction of a rising hazard just before then end of bonus eligibility. ${ }^{7}$

A different approach is provided by search theory. Search theory provides a reason other than the consumption of leisure for why an individual might choose some unemployment. This approach models the unemployed as sampling job offers until an acceptable one has been found. This process makes the time until the beginning of a job a random variable for a given individual, and simultaneously explains the determination of the person's wage rate.

Using a simplified version of the models described in Mortensen (1986). Mortensen (1987) analyzes the effects of a reemployment bonus. In his model. individuals are wealth maximizing and have a constant search intensity. New wage offers are assumed to arrive at a rate $\lambda_{0}$ per week when unemployed and $\lambda_{1}$ when employed. A wage offer $w$, is always a random draw from a stationary distribution of weekly wages with $c . d . f . F(x)$. Individuals are permanently

6 Levine (1988) simulates the effects of the bonus using four different sets of preferences and finds that between one-quarter and one-half of the sample is located at the discontinuity in the budget set. His results might be softened if incomplete participation were assumed and if preferences consistent with the initial distribution of spell lengths were chosen.

${ }^{7}$ An alternative way of examining the Illinois experiments has been suggested by David Card and is discussed in Levine (1988). Assume that it is costless to reallocate unemployment during the year. Then the Illinois experiment should only change the behavior of those who wanted to work for less than 17 weeks a year, since 17 weeks (approximately 4 months) is required to receive the bonus payment. Thus, in this scenario the budget constraint is raised by $\$ 500$ if one chooses 35 or less weeks of unemployment rather than 11 or less. 
laid off from their jobs at a rate $\delta$ per week. The unemployed receive a weekly UI benefit $b$, and are eligible for a reemployment bonus $B$ if they find a job within the first $T$ weeks of unemployment.

Given the wealth maximization assumption, the optimal job acceptance policy when unemployed sets a time dependent reservation wage which is the lowest acceptable wage offer. Let $R_{t}, t=0,1, \ldots, T$, denote this reservation wage when there are $t$ weeks remaining in the reemployment bonus qualification period. Define $w(w)$ to be the expected wealth of an individual employed at wage w and following the optimal joj offer acceptance policy. Similarly define $V_{t}, t=0,1, \ldots, T$, to be the expected wealth of an individual with $=$ weeks remaining in the reemployment bonus qualification period. The definition of the reservation wage then implies that at time $t=0$, when the reemployment bonus offer has just expired, expected wealth when employed a: the reservation wage $R_{0}$, equals the value of being unemployed, 1 . e.,

$$
v_{0}=W\left(R_{0}\right)
$$

When there are $t$ weeks remaining in the bonus qualification period, the reservation wage is the wage $R_{t}$ at which the value of employment plus the amount of the bonus equals the value of being unemployed with $t-1$ weeks remaining in the bonus period. In other words, $R_{\tau}$ solves the equation

$$
v_{t-1}=W\left(R_{t}\right)+B
$$

where $t=1,2, . . T$.

The qualitative implications of this model for the pattern of the hazard 
rate of exit from unemployment can be easily seen from these two equations. Since $V_{0}=W\left(R_{0}\right)=W\left(R_{1}\right)+B$, one sees that $R_{0}>R_{1}$. Since the reservation wage is lower during the bonus qualification period (at least at the very end of the period), the probability of a job being acceptable is higher and the hazard rate of exit from unemployment is higher. The hazard of exit from unemployment is just the product of the arrival rate of wage offers and the probability of that offer being acceptable, i. e. $\lambda_{0} \cdot\left(1-E\left(R_{t}\right)\right)$. The only force leading the value of unemployment to change over time is the length of time remaining in the eligibility period. Since it is unambiguously betcer =0 have more weeks remaining than less, one finds that $V_{t}>V_{t-1}$, implying $p_{E}<$ $R_{t-1}$ and the hazard must be lower earlier in the bonus period than later. Thus, the model implies that the hazard rises as an unemployment spell progresses until one reaches the point where bonus eligibility ends. Then, the hazard drop discretely to a constant lower level. But, one cannot tell without making additional assumptions, whether the new level of the hazard is higher or lower than the hazard at the beginning of a spell.

The operation of the Mortensen (1987) search model is clarified by the expressions for maximal expected wealth in the different employment or unemployment states. These expressions are

$$
V_{t}=b+\beta\left[\lambda_{0} \int \max \left[V_{t-1}, W(x)\right] d F(x)+\left(1-\lambda_{0}\right) V_{t-I}\right]
$$

$\mathrm{t}=1,2, \ldots . \mathrm{T}$, and 


$$
W(w)=w+\beta\left[\lambda_{1} \int \max [W(w), W(x)] d F(x)+\delta V_{T}+\left(1-\delta \cdot \lambda_{1}\right) W(w)\right]
$$

where $\beta=1 /(1+r)$ is the weekly discount factor and $r$ is the weekly interes: rate. These equations indicate that expected wealth is the sum of income received during the week and the present value of the expected end of week wealth.

Most of the simulations performed by Mortensen using this model show a sharp increase in the reemployment hazard just before the end of the bonus eligibility period. Thus, both the labor supply and search models predic: a rise in the hazard just before 11 weeks.

\section{An Analysis of the Hazard of Exit from Unemployment}

While Table 1 reported the effects of the experiments on the mean length of unemployment spells, this section analyzes the effects of the experiments on the entire distribution of spells. Table 4 displays the distribution of weeks of compensated unemployment in the first unemployment spell for the Control Group and the two experimental groups. Table 5 displays the analogous distributions of weeks of compensated unemployment in the benefit year. 8 Fo: each of the three groups the size of the risk set and the number of spells ending in each week is reported. The risk set is the set of individuals who could potentially have their spells end in the next time interval. The number

${ }^{8}$ The large number of spells of compensated unemployment with 26 or 38 weeks is explained by the potential duration of benefits in Illinois during this time period. Regular UI benefits lasted 26 weeks, while Federal Supplemental Compensation (FSC) was available during the early part of the experiment and lasted up to 12 weeks. No new FSC claims were accepted after$3 / 31 / 85$. 
of spells ending divided by the risk set gives the empirical hazard which is reported in Tables 6 and 7 . The empirical hazard in week $t$ is the rate at which spells end in week $t$ given that they have lasted until week $t$.

The differences in the distribution of weeks of compensated unemployment between the Control Group and the experimental groups is most easily seen in terms of the empirical hazard. The Claimant Experiment hazard is above the Control Group hazard especially up until and including 10 weeks. The difference between the Employer Experiment hazard and the Control Group hasard appears to fall over time, but no clear pattern is evident. One can see these differences in Figures 2 and 3. A pronounced even-odd effect where the hazard is higher in odd weeks is also apparent. This pattern is likely explained by the Ilinois requirement that one send in a certification form every two weeks to receive benefits. The certification form must list places where an individual has looked for work, interviews, etc. The first form covers the 2nd and 3 rd weeks of benefits, the next form covers the 4 ch and 5 th weeks of benefits, and so on. It appears that an appreciable number of people claim an additional week of UI that they are not entitled to, or do not bother to claim the last week that they could receive.

The differences between the experimental group hazards and the Control Group hazard may be more easily seen in Figures 4 and 5 . These figures show the hazard for two intervals. The experimental group hazards are clearly higher than the Control Group for weeks 0 to 10 . There is some indication of a higher relative hazard in the last few weeks an individual would be eligible for the bonus payment in the Claimant Experiment. Ten weeks of benefits would correspond to eleven weeks after filing for benefits because of the waiting week in Illinois. Any tendency for the experimental group hazards to be 
higher or lower than the Control Group hazards is difficult to see between 11 and 24 weeks.

To test the visual impressions given by Figures 2 through 5, I performed several score tests of the null hypothesis that the control Group and experimental hazards are the same. These tests compare one hazard to another and have greatest power against the alternative that one hazard is proportionately higher than the other. Tests for the both the Claimant Experiment $v$. the Control Group and the Employer Experiment v. the Control Group were conducted.

The test statistics $S_{j, k}$ take the following form:

$$
s_{j, k}=\frac{\left[\sum_{i=j}^{k}\left(d_{1 i} n_{2 i}-d_{2 i} n_{1 i}\right) d_{i}^{-1} \log \left(1-d_{i} n_{i}-1\right)\right]^{2}}{\sum_{i=j}^{k} q_{i} n_{1 i} n_{2 i} n_{i}^{-2}}
$$

where $a_{i}=\frac{n_{i}\left(n_{i}-d_{i}\right)}{d_{i}}\left[\log \left(1-\frac{d_{i}}{n_{i}}\right)\right]^{2}$,

$j=$ the first week of the period under examination,

$k=$ the last week of the period under examination,

$n_{1 i}=$ the size of the risk set for the control group in week $i$,

$n_{2 i}=$ the size of the risk set for the experimental group in week $i$,

$n_{i}=n_{1 i}+n_{2 i}$,

$d_{1 i}=$ the number of control group spells ending in week $i$.

$d_{2 i}=$ the number of experimental group spells ending in week $i$, and $\mathrm{d}_{i}=\mathrm{d}_{1 i}+\mathrm{d}_{2 i}$.

These test statistics are discussed in Kalbfleisch and Prentice (1980, pp. 102-3), except that here they are used to test hypotheses about intervals of the hazard rather than the entire hazard at once. The test is constructed so 
that if two hazards have different shapes, but neither hazard is on average above the other, the test will not reject. The test is very similar to the Savage log-rank test, but is more appropriate for grouped data.

The test statistics which are asymptotically distributed chi-square with one degree of freedom are reported in Table 8 . Separate tests are reported for weeks $0-10$ and weeks $11-24$. The tests indicate a sharp divergence in the patterns of the hazards between the two intervals. There is strong support for differences between the Control Group hazard and the experimental group hazards over the interval $0-10$ weeks. There is no support at all for a difference over the 11-24 week interval. I chose to end the comparisons at 24 weeks to avoid complicating the comparison with the possible effects of nearing the exhaustion of UI benefits.

A difficulty with the nonparametric hazard plots analyzed above, is that they implicitly assume that the samples are homogeneous, i. e. that all individuals in a given sample have the same hazard. Random assignment means that the distribution of heterogeneity is the same for the three groups. But, it is possible that the experimental treatments interacted with differences across individuals and caused the hazard plots to give an incorrect picture of the true effects of the experiments on the time pattern of the hazards. For example, if the experimental treatments affected those with higher underlying hazards proportionately more, an effect of the experiments on individuals after 11 weeks might be present, but might not be observable in the empirical hazard plots that do not control for such interactions. Those with higher hazards would be swept out of the distribution of remaining individuals more quickly, thus leading one to think that the experiment had no effect after 11 weeks. 
This section describes hazard models which control for differences across individuals. There are several additional advantages to estimating parametric models. Hazard models can provide estimates of the effect of an experiment on the hazard or an interval of the hazard. By controlling for individual attributes the explained variance in the model may be increased, thus improving the precision of estimated experimental effects. Lastly, the interactions between individual attributes and experimental effects may thenselves be of interest. Interactions between previous earnings and experimental effects are examined in Section 5 using the hazard model estimates.

Hazard model estimates of several specifications are reported in table 9 Time-varying explanatory variables and censoring are easily incorporated in the hazard model approach. Formally the hazard, or exit rate from unemployment, $\lambda_{i}(t)$, for individual $i$ at time $t$ is assumed to take the proportional hazards form. Let $\mathrm{T}_{\mathrm{i}}$ be the length of individual i's unemployment spell. Then the hazard at spell length $t$ is

$$
\begin{aligned}
\lambda_{i}(t) & =\lim _{h \rightarrow 0^{+}} \frac{\operatorname{prob}\left[t+h>T_{i} \geq t \mid T_{i} \geq t\right]}{h} \\
& =\lambda_{0}(t) \exp \left\{z_{i}(t)^{\prime} \beta\right\},
\end{aligned}
$$

where

$\lambda_{0}(t)$ is the baseline hazard at time $t$, which is unknown,
$z_{i}(t)$ is a vector of time dependent explanatory variables for individual $i$, and

$\beta$ is a vector of parameters which is unknown.

The estimation approach taken here minimizes functional form assumptions by allowing $\lambda_{0}(t)$ to take any form, and by incorporating in $z_{i}(t)$ many 
interactions between the covariates and time. The approach follows Prentice and Gloeckler (1978), and is extensively analyzed in Meyer (1988a). The covariate coefficients $\beta$ and the baseline hazard parameters $\gamma(t)$ are estimated using maximum likelihood techniques, where

(4.2) $\left.\quad \gamma(t)=\ln 1 \int_{t}^{t+1} \lambda_{0}(u) d u\right)$.

Table 9 reports specifications estimated using the 8,138 people in the Control Group and the Claimant Experiment. The hazard examined is the rate at which people end their first spell of UI receipt. Excluding the interactions with time and experimental status, the explanatory variables are the log of average quarterly earnings during the base period, the log of the weekly $\mathrm{UI}$ benefit anount including dependents' allowances, age, and dummy variables for race and sex. Ideally, one would like additional demographic variables, but they are not available on the public use tape.

The key variables to examine in Tabie 9 are Claimant Experiment (CE), $C E \cdot<1$ lweeks, and CE-week9orlo (Spike). The last two variables are interactions between the Claimant Experiment dummy variable and intervals of the hazard. CE.<llweeks corresponds to the interval during which the Claimant Experiment should be operative, and CE.weekgorlo is intended to capture the predicted rise in the hazard just before bonus eligibility ends.

All five specifications give similar conclusions. The coefficient estimate on $\mathrm{CE} \cdot<$ llweeks is always positive and significant. It indicates that the hazard is about 14 percent higher in the first ten weeks for the Claimant Experiment than the Control Group. The point estimate of the CE.week9orlo coefficient indicates that the Claimant Experiment hazard rises another 8 percent relative to the Control Group in the last two weeks of bonus 
eligibility, but the coefficient is never close to being significantly different from zero. The Claimant Experiment coefficient is more complicated to interpret. In specifications (1) and (3) one can see that the claimant Experiment and Control Group hazards are indistinguishable after the bonus eligibility period. To assess the effect of the Claimant Experiment variable in the other specifications one must account for the interaction terms. Interaction terms also need to be taken into account for $C E \cdot<1$ lweeks in specification (5). When interaction terms are included the total effects of the Claimant Experiment and $C E \cdot<11$ weeks are extremely close to the estimates in specification ( 1 ). The demographic variable coefficients have the expected signs, with younger workers, men and whites having higher hazards. The previous earnings and UI benefit coefficients are very close (particularly specifications (3) through (5)) to those found in Meyer (1988b). ${ }^{9}$

In summary, the Claimant Experiment is estimated to raise the hazard by about 14 percent, but only during the first 10 weeks of unemployment. The hazard is estimated to rise an additional 8 percent just before the end of bonus eligibility, but one cannot reject the hypothesis of a constant hazard. There is little evidence of any interaction effects between the claimant Experiment and individual characteristics as indicated by tests of individual interaction term coefficients, and likelihood ratio tests of groups of coefficients that can be conducted with the log-likelihood values reported at the bottom of Table 9 .

9 I tried adding gamma distributed unobserved heterogeneity to specification (5), but the unrestricted estimate of the variance was zero. 


\section{Differences in Experimental Effects by Earnings and Benefit Levels}

One might expect that formal search or labor supply models of unemployment would predict that those with lower earnings, or lower weekly LI benefit payments, would respond more to a bonus of a given dollar amount. The next few paragraphs describe theories that imply larger effects of the experiment on low income groups.

The effects of a reemployment bonus on different income groups can be predicted using the labor supply model of Ashenfelter (1980). Suppose an individual would choose to work ${ }^{*}$ weeks if not for the reemployment bonus. where $h^{*}<h^{\prime}$, and that the bonus requires at least $h^{\prime}$ weeks of work. For now, ignore the effect of the bonus on those who work more than h' weeks. Accepting the bonus will increase an individual's tisility if the amount of rha additional monetary compensation (besides the wage) required for this change in weeks worked is less than the bonus amount. The additional monetary compensation can be written as

$$
C\left(h^{\prime}, w, v\right) \equiv R\left(h^{\prime}, w^{\prime}, v\right)-w^{*} h^{\prime}-E(w, v)
$$

where $R\left(h^{\prime}, w, v\right)-w \cdot h^{\prime}$ is the constrained excess expenditure function when bonus eligibility requires $h^{\prime}$ weeks of work. W is the wage rate, $v$ is the utility level at the unconstrained optimum, and $v$ is the level of expenditures at that optimum. All prices other than the wage rate have been suppressed.

Equation (5.1) can be approximated using a second-order Taylor series expansion around the unconstrained optimum $h^{*}$. This expansion gives the 
approximation $^{10}$

(5.2) $\quad C\left(h^{\prime}, w, v\right) \approx w\left(h^{\prime}-h^{*}\right)^{2} / 2 e h^{*}$.

This equation implies that an individual will accept the bonus offer and increase his leisure to $h^{\prime}$ if

$$
w\left(h^{\prime}-h^{*}\right)^{2} / 2 \mathrm{eh}^{*}<\$ 500
$$

This inequality implies that for a given e and $h^{\frac{t}{*}}$, those with a low w are nore likely to take the reemployment borus, since the left-hand side of (5.3) is more likely to be less than $\$ 500$. This conclusion requires that differences in the labor supply elasticity e across income groups do not counterbalarce the differences in $w$. One should note that $h^{*}$ can be taken to be equal for different income groups in the sample since the differences in mean weeks of unemployment are smal1. 12

A similar prediction of larger effects of the experiment on lower income groups can be derived from Mortensen's (1987) search model. ${ }^{12}$ One way to see this is to assume that there is a scale parameter $\mu$ which proportionately shifts the distribution of wage offers and the weekly uI benefit $b$. In other

${ }^{10}$ See Ashenfelter (1980, pp. 552-553) for the derivation. The approximation proceeds by expanding the right-hand side of (6) around $h^{*}$ to obtain $\mathrm{C}\left(\mathrm{h}^{\prime}, \mathrm{w}, \mathrm{v}\right) \approx\left(\partial \mathrm{R} / \partial \mathrm{h}^{*}-\mathrm{w}\right)\left(\mathrm{h}^{\prime}-\mathrm{h}^{*}\right)+1 / 2\left(\partial^{2} \mathrm{R} / \partial \mathrm{h}^{*}\right)\left(\mathrm{h}^{\prime}-\mathrm{h}^{*}\right)^{2}$, and then uses properties of the derivatives of the right-hand side of ( 6 ) with respect to $w$ and $h^{\prime}$.

II See Table 12 for the income group means.

12 The approach here follows Mortensen (1988). 
words, $b=\mu b^{\prime}$ for some $b^{\prime}$ and the $c . d . E$. of wage offers can be written $F(x, \mu)$, where $F(x / \mu, L)=F(x, \mu)$. Also assume for now that the bonus amoun: $B=\mu B^{\prime}$ for some $B^{\prime}$. Under these assumptions, the reservation wages and the expected income functions are also shifted proportionately by $\mu$. This result can be seen by examining equation (3.3) through (3.5) above, and it implies that the hazard rate is the same for all income groups. Now note that the main empirical deviation from the above assumptions is that $B$ is constant for all income groups. $b$ is proportional to high quarter earnings in Illinois (except for the effect of dependents' allowances and the benefit cap). It seems reasonable to think of previous earnings as a proxy for the scale of the wage offer distribution. But $B$, the bonus payment, is a fixed dollar amount. so that the effect of the bonus will be larger for lower income groups. Thus, both the labor supply and search models imply that the effects of the fixed dollar amount bonus will be greatest for the low income groups.

Evidence on whether this pattern is found in the experimental results is shown in Table 10. This table reports for a number of earnings level groups the difference between the mean weeks of unemployment for the Control Group and those in the Claimant Experiment. There is no evidence of a strong cendency of those in lower earnings brackets to respond more to the fixed dollar amount bonus. The responses are remarkably similar for the different groups except for the lowest bracket in Table 10 .

Analogous tabulations are shown for benefit level groups in Table il. If there is any effect, lower benefits should also increase the effect of the bonus since lower benefit individuals would be giving up less in UI payments if they took a job more quickly. Agair, there is not a pattern in the table in this direction. That no effect of earnings is found is even more 
surprising when one acknowledges that earnings and benefits are correlated and their effects should work in the same direction.

Table 12 reports mean characteristics for different earnings level groups. The demographic variables tend to differ across the groups as one might predict. However, the key variables which might be correlated with the effects of the bonus such as mean spe:l length and frequency of satisfying the conditions for the bonus in the Control Group, and the fraction agreeing to participate in the Claimant Experiment do not differ appreciably across the earnings groups.

The lack of a relationship between previous earnings and the effect of the bonus is also evident in the hazard model estimates reported in Table 9 . These estimates control for all other available individual characteristics. The coefficients on $B P E * C E$ and $B P E * C E *<1$ weeks have the expected signs, but are never close to being significantly different from zero. Thus, the hazat model estimates do not provide any support for different effects of the Claimant Experiment on different earnings groups. It may be that this hypothesis is too subtle to detect in the data, despite having 8,138 observations. ${ }^{13}$

\section{The Possibility of Hawthorne Effects}

Since the shorter unemployment spells and apparent cost savings of the experiments are so striking, one might wonder if there could be a noneconomic

13 Another possible explanation for the lack of an earnings effect is the presence of other social insurance programs which could raise marginal tax rates for low earnings individuals. This issue cannot be tested directly in the data set, but it is not likely to be important if only 9 percent of those on UI receive other cash benefits as suggested by Scorey (1980). 
explanation for the experimental effects. Responses that come from the act of experimentation itself rather than the treatment are sometimes called Hawthorne effects. ${ }^{14}$ In the final report on the experiments spiegelman and Woodbury give two possible ways a Hawthorne effect might have appeared. They suggest that Job Service personnel could have more energetically tried to place experimental claimants. I believe they adequately respond to this possibility by pointing out that the number of placements for the Control Group and the experimental groups is the same. Alternatively, Hawthorne effects could have occurred because firms and unemploved individuals knew that shortening unemployment spells was the goal of the experiments and they wanted to please the researchers. Spiegelman and Woodbury respond that there is already a requirement that those receiving UI search for a new job.

The response to this second possibility seems less convincing, and an additional possibility should be added. Those assigned to the claimant and Employer Experiments had an interview with Job Service Personnel who explained the experiments and asked individuals to sign an agreement to participate. Those assigned to the Control Group did not go through an analogous procedure. Because of this extra attention, individuals may have received the impression that they were being observed and that their job search requirement would be more strictly enforced or that they better not claim if they were really

${ }^{14}$ The term Hawthorne effects comes Erom experiments conducted at the Hawthorne plant of the Western Electric Company in Chicago between 1924 and 1933. The first of the experiments appeared to show that changes in the level of illumination resulted in increases in worker productivity and job satisfaction whether the lighting was increased or decreased. For a critical examination of these experiments see Franke and Kaul (1978). 
employed in some manner. 15

Despite my concern about the possibility of Hawthorne effects, I think that several aspects of the results indicate that Hawthorne effects are not a serious problem. The pattern of the hazards seen in Figures 4 and 5 and Tables 6 and 7 show that the differences between the experimental hazards (particularly the Claimant Experiment) and the Control Group are concentrated in the first ten weeks when the incentive effects of the experiment are most relevant. This does not fit with Hawthorne effects which should operate throughout the entire spell.

Furthermore, the effects of the Claimant Experiment are much larger than the effects of the Employer Experiment. The difference in mean weeks of unemployment between the Claimant Experiment and the Control Group was 1.37 weeks in the first spell and 1.15 weeks in the benefit year compared to .68 and .36 weeks for the Employer Experiment compared with the Control Group. The Claimant Experiment effects are two and three times as large as those of the Employer Experiment. Larger responses are expected because the Emplover Experiment was a much more complicated treatment that required the participation of both the employer and employee. Potential employees had to explain the details of the experiment to potential employers for the experiment to work. As previously mentioned, a much smaller fraction of individuals agreed to participate in the Employer Experiment than in the Claimant Experiment. In addition, only 43 percent of those assigned to the Employer Experiment "actively participated" in the experiment while 83 percent

${ }^{15}$ If interviews with UI recipients could reduce the length of unemployment, this would be an interesting result in its own right. This point was emphasized to me by Martin Weitzman and has been made for Hawthorne effects in general by Sommer (1968). 
of those assigned to the claimant experiment did, according to a follow-up survey described in the final report. ${ }^{16}$ Because those in the Employer Experiment went through the same interview procedure, it seems safe to conclude that most of the Claimant Experiment effects are true effects rather than Hawthorne effects.

A further check that the experimental effects are the result of the bonus rather than the interviews with Job Service personnel will come from the Washington State Experiment. This experiment has six experimental groups with three different levels of the bonus and two different lengths of time by wich an individual must be reemployed. ${ }^{17}$ If one sees much larger effects for the larger bonus amounts then these differences are the result of the bonuses themselves and not Hawthorne effects.

\section{Implications for Theories of Unemployment}

This section examines the implication of the experiments for labor supply theories and search theories of unemployment. The results of the experiments call into question the applicability of the standard labor-leisure model for describing unemployment. This model predicts a sharp rise in the hazard around 10 weeks and larger effects for lower income groups. Because of the discontinuity in the budget set at 10 weeks of UI receipt, this model predicts a much higher reemployment hazard at and just before 10 weeks. While the difference between the Claimant Experiment hazard and that for the Control

${ }^{16}$ Donohue (1988) examines the differences between the effects of the Claimant Experiment and Employer Experiment and their implications for the Coase theorem.

${ }^{17}$ The Pennsylvania Experiment has a similar design. 
Group is sightly larger around 10 weeks than in the immediately preceding weeks, it is even larger earlier. To see this pattern examine Figure 4 . The spike predicted by the theory is not evident. ${ }^{18}$

Labor supply models also suggest greater effects for lower income groups as shown in section 5. This hypothesis is not supported by the data shown in Tables 10 and 21 , and the hazard model estimates of Table 9 . The experimental effects by earnings and benefit level groups suggest that a component of unemployment may be more "discretionary" for higher income groups, possibly because they have better opportunities or they can more easily vary search intensity.

Even though benefit year differences are smaller than first spell differences, one cannot conclude (at least for the Claimant Experiment) that bonus payments cause a reallocation of weeks of unemployment from before the 11 week cutoff to later periods. Smaller differences between the experimental groups and the Control Group are found when one examines the weeks of unemployment in the benefit year rather than just in the first spell. Table 1, 1ines ( $2 a$ ) and ( $2 b$ ) indicate that the difference falls from 1.37 to 1.15 weeks for the Claimant Experiment and from .68 to 36 weeks for the Emplover Experiment. ${ }^{19}$ The problem with this comparison is that the unemployment measures are weeks of compensated unemployment, and a shorter first spell will

18 A rise in the hazard is also not found just before 35 weeks of unemployment as predicted by a model where an individual can costlessly reallocate unemployment between different periods. This could be explained by there being large fixed costs to starting or ending unemployment spells.

${ }^{29}$ Even after adjusting for the longer remaining period left on average in the benefit year for the experimental groups, one continues to find a tendency for more weeks of unemployment after the end of the first spell of unemployment. 
leave more weeks of UI entitlement for future spells. If one accounts for this problem by comparing those with first spells shorter than 11 weeks, one finds that the Control Group and Claimant Experiment have the same number of weeks of compensated unemployment after the first spell. One should note that there is an incentive to keep a job for four months, once one has been found. under the bonus experiments. There is some evidence that those in the Claimant Experiment are more likely to keep a job once it has been located. but there is no difference between the Employer Experiment and the Control Group. 20

The experiments also have implications for search theories of unemployment. As discussed in Section 5. a simple search model predicts larger experimental effects for those with lower earnings, but this is not found in the data. In standard search models, indiriduals can find a job more quickly by reducing their reservation wage or increasing their search intensity. The results of the experiments suggest that changes in search intensity by individuals are more important than changes in reservation wages. The earnings measures in Tables 2 and 3 indicated that the reemployment wages of those assigned to the Claimant Experiment did not fall relative to those in the Control Group even though they spent significantly less time finding a job. 21

${ }^{20} 74.79$ percent of those in the Claimant Experiment who find a job within 11 weeks do not file for additional UI benefits within 120 days. The figure for the control group is 73.03 percent.

${ }^{2 l}$ One might wonder if the sample is large enough to detect a drop in earnings if it were present. This is a difficult question since it requires $a$ number of assumptions, but I will give a tentative answer. First, suppose an individual only reduces his reservation wage by an amount that will not reduce his total earnings over the expected lifetime of a new job. Individuals do gain the $\$ 500$ bonus amount if they satisfy the bonus requirements. The 1.37 week drop in weeks unemployed (from Table 1) then translates into a $\$ 411$ 
Standard search models where an investment in search instantaneously produces job offers also conflict with some of the experimental results. Models like the one proposed by Mortensen (1987) and described in Section 3 suggest a rapid rise in the reemployment hazard just before the 11 th week of unemployment. As previousiy observed, this pattern is not evident in the hazard.

The evidence from the experiments seems to fit a search model where choice of search intensity is important and where there is a distributed lag in the time until the start of a new job after a given investment in search, It is plausible that it would take time to arrange interviews, process applications, check references, and decide on who to employ, and then there may be a delay until the job begins because of a need to schedule training, for example. Suppose there is a lag between an investment in search and when an individual begins a job. Then if someone ever searches intensively. they would do so at the beginning of their unemployment spell, since then the investment would have a higher probability of producing a job starting before the 11 week bonus payment cutoff. Such a pattern of investment in search could produce the hazard pattern seen in Figure 4. The importance put on search intensity in this model also fits with findings that people reject ver:

increase in earnings (assuming a $\$ 300$ weekly wage) which could be balanced against lower earnings over the life of the job. The mean life of a job can be approximated by using the percentage of individuals who return to the UI rolls over a four month period $(26.97 \%)$ calculated from the Control Group. Assuming a constant hazard of job breakup, a mean job length of 4.94 quarters is implied. This figure is biased downward because the hazard probably declines over time, but it is biased upward because most people change jobs without receiving UI. Dividing the $\$ 411$ by 4.94 yields $\$ 83.2$ which is 1.53 standard deviations of the difference between lst quarter after end of first spell earnings for the Control Group and the Claimant Experiment. Thus, this suggests that about 948 of the time one should see a fall in post-unemployment earnings if it is present. 
few wage offers. 22

\section{Implications of the Experiments for Policy Design}

This section describes in turn the possibilities of firm or workex strategic behavior in response to a permanent bonus program, and the possibility of displacement effects. A key consideration in evaluating the results of the experiments and their implications for policy is the potential use of UI by firms to subsidize temporary layoffs of their employees. Firms seem attuned to the incentives created by UI systems as shown by work on the effects of incomplete UI experience rating by Brechling (1981), Topel (1983) and others. The experimental design attempted to exclude those likely to be recalled by their previous employer. However evidence from a sample of UI recipients in Missouri. ${ }^{23}$ indicates that recalls are still likely to have been important in the Illinois sample. To be eligible for assignment to one of the three groups in the Illinois experiment, an individual had to register with the stace employment service ${ }^{24}$ (which is generally separate from the UI office). To receive a bonus an individual had to find a job within 11 weeks. In the Missouri data set almost half ( 48 percent) of those registering with the employment service and finding a job within 11 weeks were recalled. Some characteristics of this Missouri data set are reported in Table 11 . People

${ }^{22}$ See U.S. Department of Labor (1975) for example. Blau (1987) provides some evidence which seems to conflict with the conventional wisdom.

${ }^{23}$ The recoded version of this data set is described in Katz and Meyer (1980)

${ }^{24}$ In both Illinois and Missouri all UI claimants are required to register with the employment service unless they have a definite recall date or are members of unions hiring through hiring halls. 
who register with the Employment Service are less likely to be recalled than others, but those with the short spells needed to qualify for the bonus payments are more likely to have been recalled.

It is likely that a similar fraction of those receiving bonuses in Illinois were recalled, ${ }^{25}$ It is also unlikely that firms' layoff and recall policies were changed by the Illinois experiments because they lasted on $\because \because 1$ weeks and were not publicized. However, in the long run firms would adjust their policies, and a bonus system like that in the Illinois experiments rouid be an enormous subsidy to temporary layoffs. An employer or employee could receive almost $\$ 1500$ each year from the state if the system were adopted on a long term basis and recalls were eligitle for the bonus. ${ }^{26}$

On alternative is to exclude recalls (as is being done in New Jersey and Washington State) but this provides some incentive to break up valuable job matches. The elasticity of match breakups may be sinal1 if they are in fac: valuable. If recalls are ineligible, not only would it eliminate the subsidy to temporary layoffs, but it might even further reduce the layoff frequency if firms want to avoid having their employees join another firm. In any case, if recalls are excluded one might still see employees rotating between similar firms.

Another issue is raised by the high frequency of recalls in the analogous Missouri sample. If the Claimant Experiment only affected half of those assigned to the experiment because the rest were awaiting recall, then the

${ }^{25}$ The New Jersey experiment sample had similar exclusions to Illinois and yet 33 percent of the sample expected to be recalled. Actual recall among those finding a job within eleven weeks was likely higher since spelis ending in recall are typically short.

${ }^{26}$ The four month work requirement after starting a job would iimit one to just under three bonuses per year. 
elasticities of job finding behavior with respect to the bonus must have been almost twice as large for the remaining population. ${ }^{27}$ Finally, one should note that if recalls are excluded, a UI bonus experiment vould only be applicable to a small fraction of the unemployed. Only about one-third of the unemployed receive UI, and only about one-third of this group is not recalled. 28

The possibility of strategic worker behavior would arise with the longrun adoption of a reemployment bonus program. It is difficult, if not impossible to choose a point in the unemployment spell when individuals become eligible for a bonus that does : te have important side effects. This problem does not appear in the experingts because they are only temporary and the problem affects experimentals and controls equally because of the randomization. Two examples from differont states will illustrate the problem.

The New Jersey experiment offered individuals large bonuses (initiâlly $\$ 1,600$ on average) beginning about the seventh week after filing for UI. This bonus amount was about five weeks wages on average. If the program were instituted on a permanent basis in this form, it would cause people with previously short spells to lengthen them to be eligible for this large bonus payment. Anyone who was planning to start a job after two weeks of UI, could increase his or her income (and leisure) by waiting another few weeks to be

27 A sizable fraction of those in the claimant Experiment did not activel: participate in the experiment (maybe because it was a temporary program). One could make a similar argument about inflating elasticites to account for incomplete participation in the experiments.

${ }^{28}$ See Burtiess (1983) and Blank and Card (1988) for the evidence on the insured unemployment rate, and Katz and Meyer (1988) for the evidence on the prevalence of recall among UI recipients 
eligible for the bonus.

The experiments in Illinois and Washington have taken the opposite approach of making a person immediately eligible for the bonus after filing for UI. This choice is likely to cause many people to file for UI who otherwise would not bother. For example, people who already have a new job lined up may now decide it is worth filing for benefits. Many people wait a few weeks before filing, and many currently never do, so that many people could potentially adjust their behavior. The mean time between the beginnirg of unemployment and filing for UI is 4.3 weeks in a sample of 380,000 inemployment spells from eight states that I am currently examining. Blank and Card (1988) estimate that 72 percent of those eligible for UI in the Current Population Survey (CPS) during 1980-82 and 83 percent of household beads eligible for UI in the Panel Study of Income Dynamics (PSID) during 1980-82 did not receive benefits. ${ }^{29}$ Even this undoubtedly misses many people with short spells or people who change jobs without unemployment who could become claimants if there were strong financial incentives to do so. The larger number of benefit payments caused by added claimants could very well eliminate any cost savings of a bonus program.

A final issue about the interpretation of the experiments is the possibility of displacement effects. Even though those in the claimant Experiment found jobs more quickly, they may have done so at the expense of other people who took longer to find jobs. These displacement effects are an important issue when determining the welfare effects of many labor market policies. The experiments in Pennsylvania and washington will try to examine

${ }^{29}$ See Blank and Card (1988) for a discussion of the differences between the CPS and PSID numbers. The population of unemployment spelis in the two surveys differ along several dimensions. 
this issue by comparing the control group to individuals in geographically separated labor markets. While I am skeptical of the ability of these experiments to measure such affects given the small fraction of job changes affected by the experiments. I plan to examine the data as they become available.

\section{Some Additional Comments and Conclusions}

The Illinois experiments show that economic incentives have strong effects on the job finding beharior of UI recipients. On the other hand. the experiments do not provide convincing evidence on the suitability of a remployment bonus program for permanent adoption. The desirability of a permanent bonus progran would depend on firm and wnker strategic responses a such a program. These responses might work to inclease unemployment and increase UI payments. Displacement effects could also reduce the desirabilit: of a bonus program. In a permanent program, a larger fraction of those who qualify for a bonus might complete the faperwork necessary to receive it. The numbers in Table 1 indicate that this would dramatically reduce the cost savings of a bonus program.

Furthermore, any full welfare analysis of a bonus system should examine the effect of the bonus on earnings of UI recipients. The savings in payments by the state UI office are just reductions in UI payments received by individuals. However, the increased earnings of li recipients might well greatly outweigh the lost benefit payments. The numbers in Tables 2 and 3 ate encouraging in this regard: those in the Clainant Experiment earn several hundred dollars more in the year following the initial clain for Li. This 
34

amount is much larger than the reduction in UI benefits received.

Finally, many of the issues discussed here implicitly deal with the isste of the design of an optimal UI system as previously discussed by Shavell and Weiss (1979) and Hausman (1984). A permanent bonus system is just another pattern of payment of UI benefits over time. Many of the issues discussed here could be applied to this literature and would suggest that the design of an optimal UI system must account for incentives for temporary layoffs as weli as the possibility of encouraging or discouraging added UI claimants. For example, if one were to move cowards a payment scheme which provided a largo lump sum payment at the beginning of an unemployment spell, this might well dramatically increase the fraction of individuals who bother to file for li and would thus increase UI payments. 
References

Ashenfelter, Orley (1980): "Unemployment as Disequilibrium in a Model of Aggregate Labor Supply," Econometrica, 48, 547-564.

Blank, Rebecca, and David Card (1988): "Recent Trends in Insured and Uninsured inemployment: Is There an Explanation?" Mimeo, Princeton: University.

Blau, David (1987): "An Analysis of Employed and Unemployed Job Search Behavior," Mimeo, University of North Carolina.

Brechling, Frank (1981): "Layoffs and Unemployment Insurance." in Studies in Labor Markets, edited by Sherwin Rosen. The Universit: of Chicago Press: Chicago, pP. 187-202.

Burtless, Gary (1983): "Why Is the Insured Unemployment Rate So Low?." Brookings Papers on Economic Activity, $225-259$.

Gorson, Walter and Susan Hilton (1982): "Unemployment Spells Public Use File Documentation, "Mimeo. Mat: ematica Policy Research.

Donohue, John J. (1988): "Di.urting the Coasian River: Incentive Schemes to Reduce Unemployment Spelis," Mimeo, Northwestern University School of Law.

Franke, Richard H., and James D. Kaul (1978): "The Hawthorne Experiments: First Statistical Interpretations," American Sociological Review, 43. $623-643$.

Hausman, Jerry A. (1984): "Tax Policy and Unemployment Insurance Effects on Labor Supply," in Removing Obstacles to Economic Growth, ed. by Michael L. Wachter and Susan M. Wachter. Philadelphia: University of Pennsylvania Press, $70-96$.

Kalbfleisch, J., and R. Prentice (1980): Statistical Analysis of Failure Time Data. New York: Wiley.

Katz, Lawrence F., and Bruce D. Meyer (1988): "Unemployment Insurance, Recall Expectations and Unemployment Outcomes," NBER Working Paper No. 2594.

Levine, Phillip B. (1988): "Analysis of the IIIinois Unemployment Insurance Experiment: A Case Against Leisure-Induced Unemployment. "unpublished, Princeton University.

Meyer, Bruce D. (1988a): "Semiparametric Estimation of Hazard Models, "mimeo, Northwestern University.

Meyer, Bruce D. (1988b): "Unemployment Insurance and Unemployment Spells," NBER Working Paper No. 2546.

Moffitt, Robert, and Walter Nicholson (1982): "The Effect of Unemployent 
Insurance on Unemployment: The Case of Federal Supplemental Benefics." The Review of Economics and Statistics, 64, 1-11.

Mortensen, Dale T. (1986): "Job Search and Labor Market Analysis," in Handbook of Labor Economics, ed. by Orley Ashenfelter and Richard Lavard. Amsterdam: North-Holland.

Mortensen, Dale T. (1987): "The Effects of a UI Bonus on Job Search," inireo. Northwestern University.

Mortensen, Dale T. (1988): "A Structural Model of UI Benefit Effects on the Incidence and Duration of Unemployment, "mimeo. Northwestern University.

Shavel1, Steven and Laurence Weiss (1979): "The Optimal Payment of Unemployment Insurance Benefics over Time, "Journal of Political Econory, $87,1347-1362$

Sommer, Robert (1968): "Hawthorne Dogma," Psychological Bulletin, 70. 3. 595.

Spiegelman, Robert $G .$, and Christopher J. O'Leary (1988): "The Washington Reemployment Bonus Demonstration: The Experimental Design, "The $\mathrm{k}$. E Upjohn Institute for Employment Research.

Spiegelman, Robert G., and Stephen A. Woodbury (1987): "The Illinois Unemployment Insurance Incentive Experiments: Final Report, "Kalamazoo: W. E. Upjohn Institute for Employment Research.

Storey, James R. (1980): "Overlap of UI Benefits and Other Income Transfer Payments," Unemployment Compensation: Studies and Research. Volume 3, National Commission on Unemployment Compensation.

Topel, Robert H. (1983): "On Layoffs and Unemployment Insurance, "The American Economic Review, 73, 541-559.

U.S. Department of Labor (1975): Jobseeking Methods Used by American workers. Bulletin 1886.

U.S. Department of Labor, Employment and Training Administration (1987): "The New Jersey Unemployment Insurance Reemployment Demonstration Project Interim Report."

U.S. Department of Labor, Employment and Training Administration (1988) "Alternative Uses of Unemployment Insurance: The UI Reemployment Demonstration Initiative."

Woodbury, Stephen A., and Robert G. Spiegelman (1987): "Bonuses to Workers and Employers to Reduce Unemployment: Randomized Trials in Illinois." American Economic Review, 77, 513-530. 
Table 1

Key Results from the Illinois Unemployment

Insurance Incentive Experiments

\begin{tabular}{|c|c|c|}
\hline Control & $\begin{array}{l}\text { Claimant } \\
\text { Experiment }\end{array}$ & $\begin{array}{l}\text { Employer } \\
\text { Experiment }\end{array}$ \\
\hline
\end{tabular}

(1) Mean Weeks of insured

unemployment
(a) First spell
18.3
17.0
(.203)
(.199)
$1 ? .7$
(b) Benefit year
20.1
(.191)
18.9
(.189)
(2. 206
19
$(.205)$

(2) Difference in weeks betwent

experimental group and

control group

(Experimental-Control.)
(a) First spell
-. $\quad-1.37$
(.284)
$-0.68$
$(.289)$
(b) Benefit year
-1.15
$(.269$
$-0.35$
$(.273)$

(3) Difference in total benefits (\$)

paid between experimental

group and control group

(Experimental-Control)
(a) First spel1
(b) Benefit year

$-2-229$

(47.1)

$-112$

$\ldots \quad-194$

-194
$(46,1)$

$-61$

$(47.1)$

(4) Percentage qualifying for bonus

$\begin{array}{lll}20.7 & 25.0 & 22.8 \\ (0.64) & (0.67) & (0.67) \\ \ldots & 13.6 & 2.8 \\ & (0.53) & (0.26) \\ 3.952 & 4.186 & 3.963\end{array}$

(6) Sample size

$\$ 500$ bonus

4.186

(48.2) 
Table 2

Mean Earnings Measures for Control Group, Glaimant Experiment, and Employer Experiment

\begin{tabular}{|c|c|c|c|c|}
\hline \multirow{2}{*}{\multicolumn{2}{|c|}{ Time Period }} & \multicolumn{3}{|c|}{ Mean Earnings in Dollars } \\
\hline & & $\begin{array}{l}\text { Control } \\
\text { Group }\end{array}$ & $\begin{array}{l}\text { Claimant } \\
\text { Experiment }\end{array}$ & $\begin{array}{l}\text { Emplo:kr } \\
\text { Experimen: }\end{array}$ \\
\hline (1) & $\begin{array}{l}\text { Average Quarterly Earnings } \\
\text { in Base Period }\end{array}$ & $\begin{array}{l}3188.31 \\
(35.89) \\
8 i=3952\end{array}$ & $\begin{array}{l}3221.98 \\
(36.91) \\
N=4186\end{array}$ & $\begin{array}{l}321+5= \\
(3-.53 \\
N=3053\end{array}$ \\
\hline (2) & Quarter before initial claim & $\begin{array}{l}3640.39 \\
(43.43) \\
N=3866\end{array}$ & $\begin{array}{l}3631.07 \\
(43.25) \\
x=4118\end{array}$ & $\begin{array}{l}3622.95 \\
(42.52) \\
x=38.9\end{array}$ \\
\hline (3) & Quarter of initial claim & $\begin{array}{l}2445.71 \\
(45.94) \\
N=3866\end{array}$ & $\begin{array}{l}2474.26 \\
(50.12) \\
N=4118\end{array}$ & $\begin{array}{l}2424.32 \\
140 \cdot 3+1 \\
\therefore=383\end{array}$ \\
\hline$(4)$ & $\begin{array}{l}\text { First full quarter after } \\
\text { initial claim }\end{array}$ & $\begin{array}{l}1230.45 \\
(31.67) \\
N=3866\end{array}$ & $\begin{array}{l}1370.70 \\
(38.41) \\
v=4118\end{array}$ & $\begin{array}{l}1272.29 \\
(32.57 \\
\mathrm{N}=38.9\end{array}$ \\
\hline (5) & $\begin{array}{l}\text { Second full quarter after } \\
\text { initial claim }\end{array}$ & $\begin{array}{l}1676.04 \\
(36.92) \\
N=3866\end{array}$ & $\begin{array}{l}1870.42 \\
(88.66) \\
N=4118\end{array}$ & $\begin{array}{l}1674.30 \\
(37.52) \\
N=3878\end{array}$ \\
\hline (6) & $\begin{array}{l}\text { Third full quarter after } \\
\text { initial claim }\end{array}$ & $\begin{array}{l}2069.94 \\
(42.17) \\
N=3866\end{array}$ & $\begin{array}{l}2072.93 \\
(39.60) \\
v=4118\end{array}$ & $\begin{array}{l}1973.58 \\
(39.41) \\
x=38,8\end{array}$ \\
\hline$(7)$ & $\begin{array}{l}\text { Year beginning with quarter } \\
\text { of initial claim (sum of } \\
\text { (3) through (6)) }\end{array}$ & $\begin{array}{l}7422.41 \\
(117.88) \\
N=3866\end{array}$ & $\begin{array}{l}7788.31 \\
(149.21) \\
N=4118\end{array}$ & $\begin{array}{l}7344 .+8 \\
(114.04) \\
N=3878\end{array}$ \\
\hline (8) & $\begin{array}{l}\text { First full quarter after } \\
\text { end of first spell }\end{array}$ & $\begin{array}{l}2057.52 \\
(39.12) \\
N=3865\end{array}$ & $\begin{array}{l}2145.53 \\
\quad(38.63) \\
N=4111\end{array}$ & $\begin{array}{l}2038.32 \\
\quad(39.15 i \\
N=3875\end{array}$ \\
\hline (9) & $\begin{array}{l}\text { Second full quarter after } \\
\text { end of first spell }\end{array}$ & $\begin{array}{c}2703.37 \\
(57.40) \\
N=2443\end{array}$ & $\begin{array}{l}2750.25 \\
(128.81) \\
N=2784\end{array}$ & $\begin{array}{l}252 \div .08 \\
(50.79) \\
N=2572\end{array}$ \\
\hline
\end{tabular}

Notes: (1) Standard Errors are in parentheses. (2) The data for these calculations came from the Public-Use Data File documented in woodbury et al. (1987). 
Table 3

Median and Trimmed Mean Earnings Measures for Control Group, Claimant Experiment, and Employer Experiment

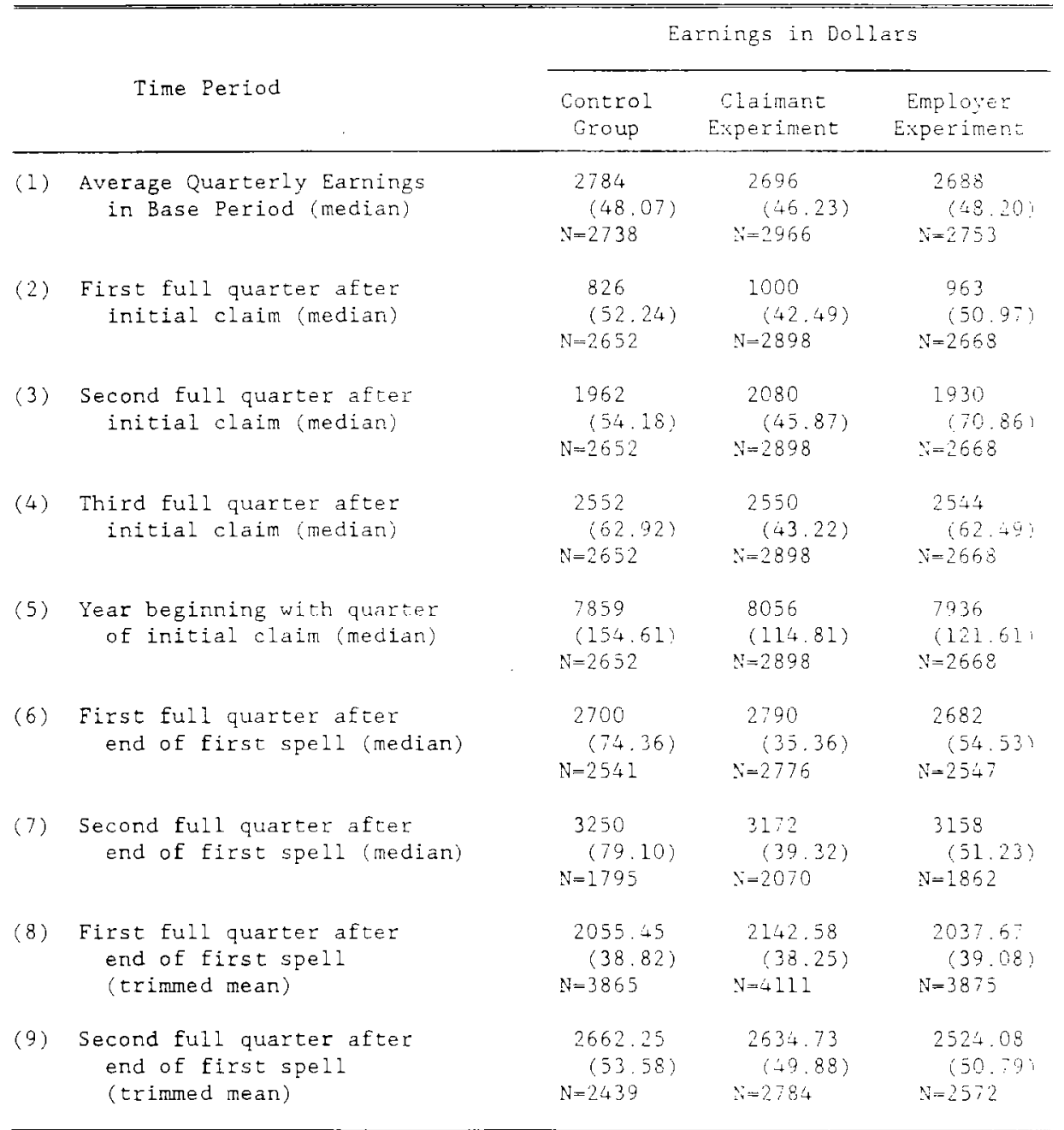

Notes: (1) Standard Errors are in parentheses. (2) The data for these calculations came from the Public-Use Data File docunented in iroodbury et al. (1987). (3) Lines 1 to 5 are calculated using only the observations with positive earnings in the second and third full quarters after the initial claim. Lines 6 and 7 are calculated using only the positive observations for each series. In all cases the standard error of the median is calculated using a Normal kernel with standard deviation 15. (4) The trimmed means include only the first $\$ 20,000$ of quarterly earnings for an individual. 
Table 4

Distribution of Weeks of Compensated Unemployment in First spell for the Control Group, Claimant Experiment, and Employer Experiment

\begin{tabular}{|c|c|c|c|c|c|c|}
\hline \multirow[t]{2}{*}{ Week } & \multicolumn{2}{|c|}{$\begin{array}{l}\text { Control } \\
\text { Group }\end{array}$} & \multicolumn{2}{|c|}{$\begin{array}{l}\text { Claimant } \\
\text { Experiment }\end{array}$} & \multicolumn{2}{|c|}{$\begin{array}{l}\text { Employer } \\
\text { Experiment }\end{array}$} \\
\hline & $\begin{array}{l}\text { Risk } \\
\text { Set }\end{array}$ & $\begin{array}{l}\text { Completed } \\
\text { Spells }\end{array}$ & $\begin{array}{l}\text { Risk } \\
\text { Set }\end{array}$ & $\begin{array}{l}\text { Completed } \\
\text { Spells }\end{array}$ & $\begin{array}{l}\text { Risk } \\
\text { Set }\end{array}$ & $\begin{array}{l}\text { Completed } \\
\text { Spells }\end{array}$ \\
\hline 0 & 3952 & 310 & 4186 & 369 & 3963 & 344 \\
\hline 1 & 3642 & 190 & 3817 & 257 & 3619 & 198 \\
\hline 2 & 3452 & 95 & 3560 & 137 & 3421 & 118 \\
\hline 3 & 3357 & 184 & 3423 & 199 & 3303 & 178 \\
\hline 4 & 3173 & 80 & 3224 & 100 & 3125 & 113 \\
\hline 5 & 3093 & 135 & 3124 & 141 & 3012 & $1 \div 9$ \\
\hline 6 & 2958 & 73 & 2983 & 93 & 2863 & 81 \\
\hline 7 & 2885 & 112 & 2890 & 141 & 2782 & 115 \\
\hline 8 & 2773 & 58 & 2749 & 72 & 2666 & 64 \\
\hline 9 & 2715 & 103 & 2677 & 120 & 2602 & 100 \\
\hline 10 & 2612 & 55 & 2557 & 80 & 2502 & 61 \\
\hline 11 & 2557 & 77 & 2477 & 80 & 2441 & 76 \\
\hline 12 & 2480 & 48 & 2397 & 51 & 2365 & 42 \\
\hline 13 & 2432 & 84 & 2346 & 85 & 2323 & 98 \\
\hline 14 & 2348 & 43 & 2261 & 46 & 2225 & 45 \\
\hline 15 & 2305 & 60 & 2215 & 70 & 2180 & 75 \\
\hline 16 & 2245 & 39 & 2145 & 37 & 2104 & +1 \\
\hline 17 & 2206 & 62 & 2108 & 70 & 2063 & 56 \\
\hline 18 & 2144 & 36 & 2038 & 40 & 2007 & 35 \\
\hline 19 & 2108 & 66 & 1998 & 61 & 1972 & 61 \\
\hline 20 & 2042 & 43 & 1937 & 36 & 1911 & 38 \\
\hline 21 & 1999 & 84 & 1901 & 57 & 1873 & 53 \\
\hline 22 & 1915 & 32 & 1844 & 32 & 1820 & 33 \\
\hline 23 & 1883 & 70 & 1812 & 72 & 1787 & 63 \\
\hline 24 & 1813 & 46 & 1740 & 40 & 1724 & 41 \\
\hline 25 & 1767 & 98 & 1700 & 93 & 1683 & 79 \\
\hline 26 & 1669 & 879 & 1607 & 847 & 1604 & 305 \\
\hline 27 & 790 & 61 & 760 & 62 & 799 & 60 \\
\hline 28 & 729 & 25 & 698 & 20 & 739 & 22 \\
\hline 29 & 704 & 13 & 678 & 19 & 717 & 24 \\
\hline 30 & 691 & 21 & 659 & 23 & 693 & 13 \\
\hline 31 & 670 & 17 & 636 & 21 & 680 & 19 \\
\hline 32 & 653 & 11 & 615 & 11 & 661 & 15 \\
\hline 33 & 642 & 13 & 604 & 13 & 646 & 12 \\
\hline 34 & .629 & 17 & 591 & 26 & 633 & 19 \\
\hline 35 & 612 & 22 & 565 & 16 & 614 & 19 \\
\hline 36 & 590 & 30 & 549 & 13 & 595 & 15 \\
\hline
\end{tabular}


41

Table 4--Continued

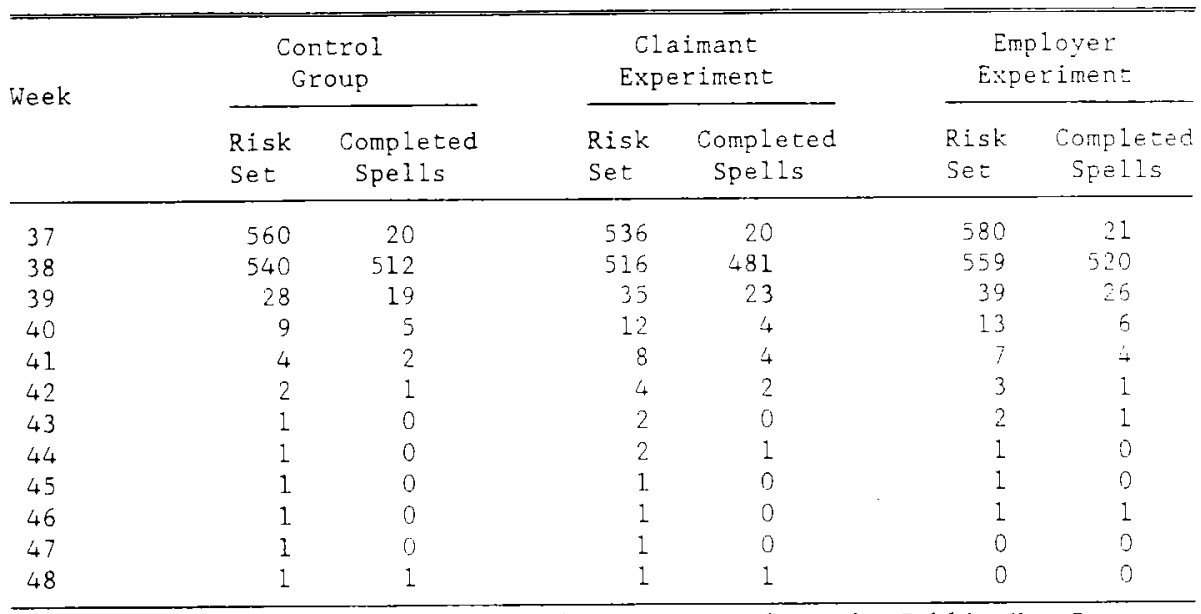

Notes: (1) The data for the si calculations came from the Public-lise Data File documented in woodbury et al. (1987). 
Table 5

Distribution of Weeks of Compensated Unemployment in Benefit Year for the Control Group, Claimant Experiment, and Employer Experiment

\begin{tabular}{|c|c|c|c|c|c|c|}
\hline \multirow{2}{*}{ Week } & \multicolumn{2}{|c|}{$\begin{array}{l}\text { Control } \\
\text { Group }\end{array}$} & \multicolumn{2}{|c|}{$\begin{array}{l}\text { Claimant } \\
\text { Experiment }\end{array}$} & \multicolumn{2}{|c|}{$\begin{array}{l}\text { Employer } \\
\text { Experiment }\end{array}$} \\
\hline & $\begin{array}{l}\text { Risk } \\
\text { Set }\end{array}$ & $\begin{array}{l}\text { Completed } \\
\text { SpeIIs }\end{array}$ & $\begin{array}{l}\text { Risk } \\
\text { Set }\end{array}$ & $\begin{array}{l}\text { Completed } \\
\text { Spells }\end{array}$ & $\begin{array}{l}\text { Risk } \\
\text { Set }\end{array}$ & $\begin{array}{l}\text { Completed } \\
\text { Spelis }\end{array}$ \\
\hline 0 & 3952 & 207 & 4186 & 254 & 3963 & 24 \\
\hline 1 & 3745 & 128 & 3932 & 178 & 3716 & 135 \\
\hline 2 & 3617 & 68 & 3754 & 96 & 3581 & 82 \\
\hline 3 & 3549 & 154 & 3658 & 157 & 3499 & $1 \div 3$ \\
\hline 4 & 3395 & 65 & 3501 & 79 & 3356 & $T-$ \\
\hline 5 & 3330 & 101 & 3422 & 122 & 3279 & $11 \therefore$ \\
\hline 6 & 3229 & 66 & 3300 & 93 & 3165 & 67 \\
\hline 7 & 3163 & 101 & 3207 & 114 & 3098 & 95 \\
\hline 8 & 3062 & 59 & 3093 & 79 & 3003 & 54 \\
\hline 9 & 3003 & 93 & 3014 & 111 & 2949 & 97 \\
\hline 10 & 2910 & 54 & 2903 & 73 & 2852 & 59 \\
\hline 11 & 2856 & 70 & 2830 & 86 & 2793 & 74 \\
\hline 12 & 2786 & 54 & 2744 & 54 & 2719 & 43 \\
\hline 13 & 2732 & 85 & 2590 & 90 & 2676 & 83 \\
\hline 14 & 2647 & 45 & 2600 & 39 & 2593 & 56 \\
\hline 15 & 2602 & 70 & 2561 & 75 & 2537 & 80 \\
\hline 16 & 2532 & 57 & 2486 & 39 & 2457 & 48 \\
\hline 17 & 2475 & 83 & 2447 & 81 & 2409 & 63 \\
\hline 18 & 2392 & 43 & 2366 & 48 & 2346 & 40 \\
\hline 19 & 2349 & 62 & 2318 & 69 & 2306 & 71 \\
\hline 20 & 2287 & 38 & 2249 & 41 & 2235 & 43 \\
\hline 21 & 2249 & 78 & 2208 & 62 & 2192 & 69 \\
\hline 22 & 2171 & 40 & 2146 & 36 & 2123 & 41 \\
\hline 23 & 2131 & 84 & 2110 & 85 & 2082 & 88 \\
\hline 24 & 2047 & 48 & 2025 & 58 & 1994 & 5. \\
\hline 25 & 1999 & 109 & 1967 & 101 & 1937 & 97 \\
\hline 26 & 1890 & 1047 & 1866 & 1029 & 1840 & 972 \\
\hline 27 & 843 & 82 & 837 & 107 & 868 & 88 \\
\hline 28 & 761 & 31 & 730 & 24 & 780 & 33 \\
\hline 29 & 730 & 17 & 706 & 22 & 747 & 26 \\
\hline 30 & 713 & 22 & 684 & 27 & 721 & If \\
\hline 31 & 691 & 18 & 657 & 24 & 705 & $2 ?$ \\
\hline 32 & 673 & 14 & 633 & 13 & 683 & I6 \\
\hline 33 & 659 & 14 & 620 & 14 & 667 & 14 \\
\hline 34 & 645 & 17 & 606 & 27 & 653 & 20 \\
\hline 35 & 628 & 23 & 579 & 17 & 633 & 20 \\
\hline 36 & 605 & 31 & 562 & 13 & 613 & 15 \\
\hline
\end{tabular}


43

Table 5--Continued

\begin{tabular}{|c|c|c|c|c|c|c|}
\hline \multirow{2}{*}{ Week } & \multicolumn{2}{|c|}{$\begin{array}{l}\text { Control } \\
\text { Group }\end{array}$} & \multicolumn{2}{|c|}{$\begin{array}{l}\text { Claimant } \\
\text { Experiment }\end{array}$} & \multicolumn{2}{|c|}{$\begin{array}{l}\text { Enployer } \\
\text { Experiment }\end{array}$} \\
\hline & $\begin{array}{l}\text { Risk } \\
\text { Set }\end{array}$ & $\begin{array}{l}\text { Completed } \\
\text { Spelis }\end{array}$ & $\begin{array}{l}\text { Risk } \\
\text { Set }\end{array}$ & $\begin{array}{l}\text { Completed } \\
\text { Spelis }\end{array}$ & $\begin{array}{l}\text { Risk } \\
\text { Set }\end{array}$ & $\begin{array}{l}\text { Completed } \\
\text { Spells }\end{array}$ \\
\hline 37 & 574 & 21 & 549 & 20 & 598 & 22 \\
\hline 38 & 553 & 522 & 529 & 491 & 576 & 532 \\
\hline 39 & 31 & 21 & 38 & 25 & 43 & 20 \\
\hline 40 & 10 & 5 & 13 & 4 & 14 & 5 \\
\hline 41 & 4 & 2 & 9 & 5 & 8 & 4 \\
\hline 42 & 2 & 1 & 4 & 2 & 4 & 1 \\
\hline 43 & 1 & 0 & 2 & 0 & 3 & 2 \\
\hline 44 & 1 & 0 & 2 & 1 & 1 & 0 \\
\hline 45 & 1 & 0 & 1 & 0 & 1 & D \\
\hline 46 & 1 & 0 & 1 & 0 & 1 & 1 \\
\hline 47 & 1 & 0 & 1 & 0 & 0 & 0 \\
\hline 48 & 1 & 1 & 1 & 1 & 0 & 0 \\
\hline
\end{tabular}

Notes: (I) The data for these calculations came from the Public-lse Data File documented in Woodbury et al. (1987). 
Table 6

Empirical Hazard for the First Spell of Compensated Unemployment for the Control Group, Glaimant Experiment, and Employer Experiment

\begin{tabular}{|c|c|c|c|}
\hline \multirow[b]{2}{*}{ Week } & \multicolumn{3}{|c|}{ Empirical Hazard } \\
\hline & $\begin{array}{l}\text { Control } \\
\text { Group }\end{array}$ & $\begin{array}{c}\text { Claimant } \\
\text { Experiment }\end{array}$ & $\begin{array}{l}\text { Employer } \\
\text { Experiment }\end{array}$ \\
\hline 0 & 0.0784 & 0.0882 & 0.0868 \\
\hline 1 & 0.0522 & 0.0673 & 0.0547 \\
\hline 2 & 0.0275 & 0.0385 & 0.0345 \\
\hline 3 & 0.0548 & 0.0581 & 0.0539 \\
\hline 4 & 0.0252 & 0.0310 & 0.0362 \\
\hline 5 & 0.0436 & 0.0451 & 0.0495 \\
\hline 6 & 0.0247 & 0.0312 & 0.0283 \\
\hline 7 & 0.0388 & 0.0488 & 0.0417 \\
\hline 8 & 0.0209 & 0.0262 & 0.0240 \\
\hline 9 & 0.0379 & 0.0448 & 0.0384 \\
\hline 10 & 0.0211 & 0.0313 & 0.0244 \\
\hline 11 & 0.0301 & 0.0323 & 0.0311 \\
\hline 12 & 0.0194 & 0.0213 & 0.0178 \\
\hline 13 & 0.0345 & 0.0362 & 0.0422 \\
\hline 14 & 0.0183 & 0.0203 & 0.0202 \\
\hline 15 & 0.0260 & 0.0316 & 0.0349 \\
\hline 16 & 0.0174 & 0.0172 & 0.0195 \\
\hline 17 & 0.0281 & 0.0332 & 0.0271 \\
\hline 18 & 0.0168 & 0.0196 & 0.0174 \\
\hline 19 & 0.0313 & 0.0305 & 0.0309 \\
\hline 20 & 0.0211 & 0.0186 & 0.0199 \\
\hline 21 & 0.0420 & 0.0300 & 0.0283 \\
\hline 22 & 0.0167 & 0.0174 & 0.0181 \\
\hline 23 & 0.0372 & C. 0397 & 0.0353 \\
\hline 24 & 0.0254 & C. 0230 & 0.0238 \\
\hline 25 & 0.0555 & C. .0547 & 0.0469 \\
\hline 26 & 0.5267 & 0.5271 & 0.5019 \\
\hline 27 & 0.0772 & c. 0816 & 0.0751 \\
\hline 28 & 0.0343 & 0.0287 & 0.0298 \\
\hline 29 & 0.0185 & 0.0280 & 0.0335 \\
\hline 30 & 0.0304 & 0.0349 & 0.0188 \\
\hline 31 & 0.0254 & 0.0330 & 0.0279 \\
\hline 32 & 0.0168 & 0.0179 & 0.0227 \\
\hline 33 & 0.0202 & 0.0215 & 0.0201 \\
\hline 34 & 0.0270 & 0.0440 & 0.0300 \\
\hline 35 & 0.0359 & 0.0283 & 0.0309 \\
\hline 36 & 0.0508 & 0.0237 & 0.0252 \\
\hline
\end{tabular}


Table 6--Continued

Empirical Hazard

\begin{tabular}{lccc}
\cline { 2 - 3 } Week & $\begin{array}{c}\text { Control } \\
\text { Group }\end{array}$ & $\begin{array}{c}\text { Ciaimant } \\
\text { Experiment }\end{array}$ & $\begin{array}{c}\text { Employer } \\
\text { Experiment }\end{array}$ \\
\hline 37 & 0.0357 & 0.0373 & 0.0362 \\
38 & 0.9481 & 0.9322 & 0.9302 \\
39 & 0.6786 & 0.6571 & 0.6667 \\
40 & 0.5556 & 0.3333 & 0.4615 \\
41 & 0.5000 & 0.5000 & 0.5714 \\
42 & 0.5000 & 0.5000 & 0.3333 \\
43 & 0.0000 & 0.0000 & 0.5000 \\
44 & 0.0000 & 0.5000 & 0.0000 \\
45 & 0.0000 & 0.0000 & 0.0000 \\
46 & 0.0000 & 0.0000 & 1.0000 \\
47 & 0.0000 & 0.0000 & 0.0000 \\
48 & 1.0000 & 2.0000 & 0.0000 \\
\hline
\end{tabular}

Notes: (1) The data for these Calculations came from the Public-Use Data File documented in Woodbury et al. (1987). 
Table 7

Empirical Hazard for Weeks of Compensated Unemployment in the Benefit Year for the Control Group, Claimant Experiment, and Employer Experiment

\begin{tabular}{|c|c|c|c|}
\hline \multirow[b]{2}{*}{ Week } & \multicolumn{3}{|c|}{ Empirical Hazard } \\
\hline & $\begin{array}{l}\text { Control } \\
\text { Group }\end{array}$ & $\begin{array}{c}\text { Claimant } \\
\text { Experiment }\end{array}$ & $\begin{array}{c}\text { Employer } \\
\text { Experiment }\end{array}$ \\
\hline 0 & 0.0524 & 0.0607 & 0.0623 \\
\hline 1 & 0.0342 & 0.0453 & 0.0363 \\
\hline 2 & 0.0188 & 0.0256 & 0.0229 \\
\hline 3 & 0.0434 & 0.0429 & 0.0409 \\
\hline 4 & 0.0191 & 0.0226 & 0.0229 \\
\hline 5 & 0.0303 & 0.0357 & 0.0348 \\
\hline 6 & 0.0204 & 0.0282 & 0.0212 \\
\hline 7 & 0.0319 & 0.0355 & 0.0307 \\
\hline 8 & 0.0193 & 0.0255 & 0.0180 \\
\hline 9 & 0.0310 & 0.0368 & 0.0329 \\
\hline 10 & 0.0186 & 0.0251 & 0.0207 \\
\hline 11 & 0.0245 & 0.0304 & 0.0265 \\
\hline 12 & 0.0194 & 0.0197 & 0.0158 \\
\hline 13 & 0.0311 & 0.0335 & 0.0310 \\
\hline 14 & 0.0170 & 0.0150 & 0.0216 \\
\hline 15 & 0.0269 & 0.0293 & 0.0315 \\
\hline 16 & 0.0225 & 0.0157 & 0.0195 \\
\hline 17 & 0.0335 & 0.0331 & 0.0262 \\
\hline 18 & 0.0180 & 0.0203 & 0.0171 \\
\hline 19 & 0.0264 & 0.0298 & 0.0308 \\
\hline 20 & 0.0166 & 0.0182 & 0.0192 \\
\hline 21 & 0.0347 & 0.0281 & 0.0315 \\
\hline 22 & 0.0184 & 0.0168 & 0.0193 \\
\hline 23 & 0.0394 & 0.0403 & 0.0423 \\
\hline 24 & 0.0234 & 0.0286 & 0.0286 \\
\hline 25 & 0.0545 & 0.0513 & 0.0501 \\
\hline 26 & 0.5540 & 0.5514 & 0.5283 \\
\hline 27 & 0.0973 & 0.1278 & 0.1014 \\
\hline 28 & 0.0407 & 0.0329 & 0.0423 \\
\hline 29 & 0.0233 & 0.0312 & 0.0348 \\
\hline 30 & 0.0309 & 0.0395 & 0.0222 \\
\hline 31 & 0.0260 & 0.0365 & 0.0312 \\
\hline 32 & 0.0208 & 0.0205 & 0.0234 \\
\hline 33 & 0.0212 & 0.0226 & 0.0210 \\
\hline 34 & 0.0264 & 0.0446 & 0.0306 \\
\hline 35 & 0.0366 & 0.0294 & 0.0316 \\
\hline 36 & 0.0512 & 0.0231 & 0.0245 \\
\hline
\end{tabular}


Table 7--Continued

\begin{tabular}{lccc}
\hline Week & \multicolumn{3}{c}{ Empirical Hazard } \\
\cline { 2 - 4 } & $\begin{array}{c}\text { Control } \\
\text { Group }\end{array}$ & $\begin{array}{c}\text { Claimant } \\
\text { Experiment }\end{array}$ & $\begin{array}{c}\text { Employer } \\
\text { Experiment }\end{array}$ \\
\hline 37 & 0.0366 & 0.0364 & 0.0358 \\
38 & 0.9439 & 0.9282 & 0.9253 \\
39 & 0.6774 & 0.6579 & 0.6744 \\
40 & 0.6000 & 0.3077 & 0.4286 \\
41 & 0.5000 & 0.5556 & 0.5000 \\
42 & 0.5000 & 0.5000 & 0.2500 \\
43 & 0.0000 & 0.0000 & 0.6667 \\
44 & 0.0000 & 0.5000 & 0.0000 \\
45 & 0.0000 & 0.0000 & 0.0000 \\
46 & 0.0000 & 0.0000 & 1.0000 \\
47 & 0.0000 & 0.0000 & 0.0000 \\
48 & 1.0000 & 1.0000 & 0.0000 \\
\hline
\end{tabular}

Notes: (1) The data for these calculations came from the Public-lse Data File documented in woodbury et al. (1987). 
Table 8

Score Tests for a Proportional Shift in the Hazard Between the Control and Experimental Groups

(1) Control Group v. Claimant Experiment
(a) First spell
25.86
.25
(b) Benefit year
20.83
1.9

(2) Control Group v. Employer Experiment
(a) First spe11
8.33
.09
(b) Benefit year
3.48
$2 ?$

Notes: (1) See the text for the construction of the test statistics (2) Under the null hypothesis of equal hazards the cest statistics are asymptotically chi-square with one degree of freedorn. The critical values for the test are 3.84 and 6.64 at the .05 and .01 level respectively. 
Table 9

Estimates of the First Spell Hazard Rate

for the Combined Control Group and Claimant Experiment Sample ${ }^{a}$

(Sample Size $=8138)$

\begin{tabular}{|c|c|c|c|c|c|}
\hline \multirow{2}{*}{ Variable } & \multicolumn{5}{|c|}{ Specification } \\
\hline & (1) & (2) & (3) & (4) & (5) \\
\hline Age & $\begin{array}{c}-.0126 \\
(0.0017)\end{array}$ & $\begin{array}{c}-.0117 \\
(0.0025)\end{array}$ & $\begin{array}{c}-.0125 \\
(0.0030)\end{array}$ & $\begin{array}{c}-.0117 \\
(0.0035)\end{array}$ & $(0.0146)$ \\
\hline $\begin{array}{l}\text { Log Base Period } \\
\text { Earnings (BPE) }\end{array}$ & $\begin{array}{c}.2700 \\
(0.0400)\end{array}$ & $\begin{array}{l}.2972 \\
(0.0593)\end{array}$ & $\begin{array}{c}.4751 \\
(0.0693)\end{array}$ & $\begin{array}{l}.4937 \\
(0.0811)\end{array}$ & $\begin{array}{l}.4737 \\
(0.1022)\end{array}$ \\
\hline Black $=1$ & $\begin{array}{l}-.5205 \\
(0.0367)\end{array}$ & $\begin{array}{c}-.5195 \\
(0.0534)\end{array}$ & $\begin{array}{l}-.5919 \\
(0.0640)\end{array}$ & $\begin{array}{c}-.5889 \\
(0.0735)\end{array}$ & $\begin{array}{r}-.3366 \\
0.0888\end{array}$ \\
\hline Male $=1$ & $\begin{array}{c}.0899 \\
(0.0301)\end{array}$ & $\begin{array}{c}.1006 \\
(0.0441)\end{array}$ & $(0.0526)$ & $\begin{array}{c}.1779 \\
(0.0606)\end{array}$ & $\begin{array}{c}.1243 \\
(0.0739)\end{array}$ \\
\hline Log UI Benefit (BEN) & $\begin{array}{c}-.4655 \\
(0.0660)\end{array}$ & $\begin{array}{c}-.5715 \\
(0.0976)\end{array}$ & $\begin{array}{r}-6: 15 \\
(0.12: 8)\end{array}$ & $\begin{array}{l}.7063 \\
(0.1357)\end{array}$ & $\begin{array}{l}-.6345 \\
(0.1705)\end{array}$ \\
\hline Claimant Experiment (CE) & $(0.0146)$ & $(0.3381)$ & $(0.0307)$ & $\begin{array}{c}-.5565 \\
(0.3414)\end{array}$ & $\begin{array}{c}-.5883 \\
(0.5961)\end{array}$ \\
\hline$C E \cdot<11$ weeks & $(0.0635)$ & $(0.0636)$ & $(0.0637)$ & $\begin{array}{c}.1490 \\
(0.0639)\end{array}$ & $\begin{array}{l}.1529 \\
(0.0647)\end{array}$ \\
\hline CE.week9orlo (Spike) & $\begin{array}{c}.0849 \\
(0.1133)\end{array}$ & $(0.0844$ & $\begin{array}{r}.0851 \\
(0.1133)\end{array}$ & $\begin{array}{c}.0848 \\
(0.1134)\end{array}$ & $\begin{array}{r}.0839 \\
(0.1134)\end{array}$ \\
\hline Age $\cdot C E$ & $\cdots$ & $(0.0018)$ & - . & $\begin{array}{c}-.0019 \\
(0.0035)\end{array}$ & $\begin{array}{c}.0040 \\
60.0061 !\end{array}$ \\
\hline $\mathrm{BPE} \cdot \mathrm{CE}$ & $\ldots$ & $\begin{array}{c}-.0505 \\
(0.0802)\end{array}$ & $\cdots$ & $\begin{array}{c}-.0367 \\
(0.0796)\end{array}$ & $(0.1388)$ \\
\hline Black $\cdot C E$ & - . & $\begin{array}{l}-.0028 \\
(0.0737)\end{array}$ & $\ldots$ & $\begin{array}{c}-.0073 \\
(0.0743)\end{array}$ & $\begin{array}{l}-.1176 \\
(0.1284)\end{array}$ \\
\hline Male $\cdot \mathrm{CE}$ & $\cdots$ & $\begin{array}{c}. .0202 \\
(0.0603)\end{array}$ & - . & $\begin{array}{c}-.0141 \\
(0.0605)\end{array}$ & $\begin{array}{r}.0921 \\
(0.1053)\end{array}$ \\
\hline$B E N \cdot C E$ & - & $\begin{array}{c}.2006 \\
(0.1324)\end{array}$ & $-\cdots$ & $\begin{array}{r}.1917 \\
(0.1323)\end{array}$ & $\begin{array}{c}.0855 \\
(0.2359)\end{array}$ \\
\hline
\end{tabular}


Table 9--Continued

\begin{tabular}{|c|c|c|c|c|c|}
\hline \multirow{2}{*}{ Variable } & \multicolumn{5}{|c|}{ Specification } \\
\hline & (1) & $(2)$ & (3) & (4) & (5) \\
\hline Age $\cdot<11$ weeks & $\cdots$ & --- & $\begin{array}{c}-.0003 \\
(0.0037)\end{array}$ & $\begin{array}{c}.0002 \\
(0.0037)\end{array}$ & $\frac{-.0002}{\left(0.003^{-i}\right.}$ \\
\hline $\mathrm{BPE} \cdot<1$ 1weeks & $\cdots$ & $\cdots$ & $\begin{array}{l}-.3047 \\
(0.0843)\end{array}$ & $\begin{array}{l}. .3030 \\
(0.0843)\end{array}$ & $\begin{array}{l}-.3021 \\
(0.0845)\end{array}$ \\
\hline Black $<<1$ weeks & $-\cdots$ & $\cdots$ & $\begin{array}{l}.1114 \\
(0.0790)\end{array}$ & $(0.0792)$ & $(0.0792)$ \\
\hline Male $\cdot<l l$ weeks & $-\cdot$ & $\cdots$ & $\begin{array}{c}-.1212 \\
(0.0646)\end{array}$ & $(0.0647)$ & $\begin{array}{l}.1195 \\
(0.064)\end{array}$ \\
\hline $\mathrm{BEN} \cdot<11$ weeks & $\cdots$ & $\cdots$ & $\begin{array}{r}.2195 \\
(0.1449)\end{array}$ & $\begin{array}{c}.2099 \\
(0.1450)\end{array}$ & $\begin{array}{l}.2118 \\
(0.1453)\end{array}$ \\
\hline Age $\cdot \mathrm{CE} \cdot<11$ weeks & $\cdots$ & $\cdots$ & $-\cdots$ & $\cdots$ & $\begin{array}{c}-.0090 \\
(0.0074)\end{array}$ \\
\hline $\mathrm{BPE} \cdot \mathrm{CE} \cdot<11$ weeks & $\cdots$ & $\cdots$ & $\cdots$ & $\cdots$ & $\begin{array}{l}-.0643 \\
(0.1692)\end{array}$ \\
\hline Black $\cdot C E \cdot<1$ lweeks & -- & $-\cdots$ & $-\cdots$ & $\cdots$ & $\begin{array}{c}.1680 \\
(0.1584)\end{array}$ \\
\hline Male $\cdot C E \cdot<1$ lweeks & $\cdots$ & $\cdots$ & $-\cdots$ & $\cdots$ & $\begin{array}{l}-.1604 \\
(0.1295)\end{array}$ \\
\hline $\mathrm{BEN} \cdot \mathrm{CE} \cdot<1$ lweeks & $\cdots$ & $-\cdots$ & $-\cdots$ & $-\cdots$ & $\begin{array}{l}.1674 \\
(0.2908)\end{array}$ \\
\hline $\begin{array}{l}\text { Log-1ikelihood value } \\
(+20000)\end{array}$ & 566.25 & 568.12 & 582.88 & 584.95 & 587.16 \\
\hline
\end{tabular}

${ }^{a}$ Standard errors are shown in parentheses. The means and standard deviations of the key variables in the specifications are:

$\begin{array}{lccccccc} & \text { First Spell } & \text { Age } & \text { BPE } & \text { Black } & \text { Male } & \text { BEN } & \text { CE } \\ \text { Mean } & 16.33 & 32.95 & 7.83 & .26 & .56 & 4.83 & .51 \\ \text { Standard Dev. } & 9.98 & 8.86 & .73 & .44 & .50 & .43 & .50\end{array}$

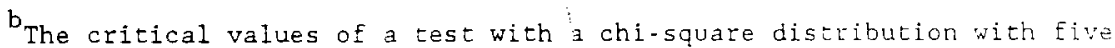
degrees of freedom are 11.07 and 15.09 at the .05 and .01 levels respectively. 
Table 10

The Responsiveness of Different Income Groups to the Claimant Experiment

\begin{tabular}{|c|c|c|c|}
\hline $\begin{array}{l}\text { Average Quarterly } \\
\text { Base Period Earnings } \\
\text { (dollars) }\end{array}$ & $\begin{array}{c}\text { Difference in Mean } \\
\text { Weeks in First Spe11 } \\
\text { (experimentals }\end{array}$ & $\begin{array}{l}\text { Difference in Mean } \\
\text { Weeks in Benefit Year } \\
\text { nus controls) }\end{array}$ & $\begin{array}{l}\text { Sample } \\
\text { Sizes }\end{array}$ \\
\hline$<1200$ & $\begin{array}{l}-.370 \\
(.664)\end{array}$ & $\begin{array}{l}-.074 \\
(.626)\end{array}$ & $\begin{array}{l}\mathrm{N}=6.2 \\
\mathrm{~N}_{\mathrm{e}}^{\mathrm{C}}=720\end{array}$ \\
\hline $1200-1999$ & $\begin{array}{r}-1.445 \\
(.662)\end{array}$ & $\begin{array}{r}-1.221 \\
(.621)\end{array}$ & $\begin{array}{l}\mathrm{N}^{\mathrm{C}}=722 \\
\mathrm{~N}_{\mathrm{e}}=.39\end{array}$ \\
\hline $2000-2999$ & $\begin{array}{r}-1.091 \\
(.647)\end{array}$ & $\begin{array}{r}-1.175 \\
(.609)\end{array}$ & $\begin{array}{l}N_{e}=7.8 \\
N_{e}=866\end{array}$ \\
\hline $3000-4000$ & $\begin{array}{r}-1.958 \\
(.726)\end{array}$ & $\begin{array}{r}-1.832 \\
(.687)\end{array}$ & $\begin{array}{l}N=539 \\
v=594\end{array}$ \\
\hline $4001-5000$ & $\begin{array}{r}-2.192 \\
(.870)\end{array}$ & $\begin{array}{r}-1.299 \\
(.838)\end{array}$ & $\begin{array}{l}N=472 \\
V_{e}^{c}=414\end{array}$ \\
\hline$>5000$ & $\begin{array}{r}-1.456 \\
(.657)\end{array}$ & $\begin{array}{r}-1.353 \\
(.630)\end{array}$ & $\begin{array}{l}\mathrm{N}=569 \\
\mathrm{~N}_{\mathrm{e}}^{\mathrm{C}}=734\end{array}$ \\
\hline
\end{tabular}

Notes: (1) Standard Errors are in parentheses, (2) The data for these calculations came from the Public-Use Dasa File docunonted in Woodbury et al. (1987). (3) $\mathrm{N}$ is the sample size for the Control Group and $\mathrm{N}$ is the sample size for the Claimant Experiment. 
Table 11

The Responsiveness of Different Benefit Level

Groups to the Claimant Experiment

\begin{tabular}{|c|c|c|c|}
\hline $\begin{array}{l}\text { Weekly Benefit } \\
\text { Amount } \\
\text { (dollars) }\end{array}$ & $\begin{array}{r}\text { Difference in Mean } \\
\text { Weeks in First Spell } \\
\text { (experimentals }\end{array}$ & $\begin{array}{l}\text { Difference in Mean } \\
\text { Weeks in Benefit Year } \\
\text { minus controls) }\end{array}$ & $\begin{array}{l}\text { Sample } \\
\text { Sizes }\end{array}$ \\
\hline$<86$ & $\begin{array}{l}-.898 \\
(.599)\end{array}$ & $\begin{array}{l}-.691 \\
(.568)\end{array}$ & $\begin{array}{l}N_{c}=85 \\
N_{e}^{C}=925\end{array}$ \\
\hline $86-120$ & $\begin{array}{r}-2.014 \\
(.682)\end{array}$ & $\begin{array}{r}-2.090 \\
(.644)\end{array}$ & $\begin{array}{l}\mathrm{N}^{\mathrm{c}}=56 \mathrm{i} \\
\mathrm{N}_{e}=745\end{array}$ \\
\hline $121-160$ & $\begin{array}{l}-.102 \\
(.667)\end{array}$ & $\begin{array}{l}-.367 \\
(.634)\end{array}$ & $\begin{array}{l}\mathrm{N}^{\mathrm{c}}=710 \\
\mathrm{~N}_{\mathrm{e}}=783\end{array}$ \\
\hline $161-208$ & $\begin{array}{r}-1.583 \\
(.581)\end{array}$ & $\begin{array}{l}-.820 \\
(.554)\end{array}$ & $\begin{array}{l}\mathrm{N}_{c}=973 \\
\mathrm{~N}_{\mathrm{e}}=983\end{array}$ \\
\hline 209 & $\begin{array}{r}-2.260 \\
(.660)\end{array}$ & $\begin{array}{r}-2.002 \\
(.620)\end{array}$ & $\begin{array}{l}\mathrm{N}^{\mathrm{C}}=738 \\
\mathrm{~N}_{\mathrm{e}}^{\mathrm{C}}=7 / 29\end{array}$ \\
\hline
\end{tabular}

Notes: (i) Standard Errors are in parentheses. (2) The data for these calculations came from the Public-Use Data File documented in Woodbury et al. (1987). (3) $\mathrm{N}$ is the sample size for the Control Group and $\mathrm{N}$ is the sample size for the CIaimant Experiment. (4) Weekly Benefit Amount includes dependents. allowances. 
Table 12

Income Group Means of Key Varlables

\begin{tabular}{|c|c|c|c|c|c|c|}
\hline \multirow[b]{2}{*}{$\begin{array}{l}\text { Mean Quarterly } \\
\text { Base Period } \\
\text { Earnings } \\
\text { (dollars) }\end{array}$} & \multicolumn{5}{|c|}{ Control Group } & \multirow{2}{*}{$\begin{array}{c}\text { Claimant } \\
\text { Experiment } \\
\text { Percent } \\
\text { Agreeing to } \\
\text { Participate }\end{array}$} \\
\hline & $\begin{array}{l}\text { Mean } \\
\text { Eirst } \\
\text { Spell } \\
\text { (weeks) }\end{array}$ & $\begin{array}{r}\text { Mean } \\
\text { Age }\end{array}$ & $\begin{array}{c}\text { Percent } \\
\text { Black }\end{array}$ & $\begin{array}{c}\text { Peicent } \\
\text { Male }\end{array}$ & $\begin{array}{l}\text { Percent } \\
\text { Eligible } \\
\text { for Bonus }\end{array}$ & \\
\hline$<1200$ & $\begin{array}{l}16.73 \\
(0.48)\end{array}$ & $\begin{array}{l}30.64 \\
(0.33)\end{array}$ & $\begin{array}{l}37.50 \\
(1.87)\end{array}$ & $\begin{array}{l}48.36 \\
(1.93)\end{array}$ & $\begin{array}{l}21.73 \\
(1.59)\end{array}$ & $\begin{array}{l}90.29 \\
(1.13)\end{array}$ \\
\hline $1200-1999$ & $\begin{array}{l}18.67 \\
(0.47)\end{array}$ & $\begin{array}{l}31.42 \\
(0.33)\end{array}$ & $\begin{array}{l}35.32 \\
(1.78)\end{array}$ & $\begin{array}{l}49.03 \\
(1.86)\end{array}$ & $\begin{array}{l}19.67 \\
(1.48)\end{array}$ & $\begin{array}{l}87.73 \\
(1.23)\end{array}$ \\
\hline $2000-2999$ & $\begin{array}{l}18.76 \\
(0.46)\end{array}$ & $\begin{array}{l}32.01 \\
(0.32)\end{array}$ & $\begin{array}{l}26.09 \\
(1.58)\end{array}$ & $\begin{array}{l}50.90 \\
(1.79)\end{array}$ & $\begin{array}{l}19.92 \\
(1.43)\end{array}$ & $\begin{array}{l}86.86 \\
(1.19)\end{array}$ \\
\hline $3000-4000$ & $\begin{array}{l}19.56 \\
(0.51)\end{array}$ & $\begin{array}{l}33.11 \\
(0.36)\end{array}$ & $\begin{array}{l}18.62 \\
(1.54)\end{array}$ & $\begin{array}{l}48.20 \\
(1.98)\end{array}$ & $\begin{array}{l}18.62 \\
(1.54)\end{array}$ & $\begin{array}{l}88.14 \\
(1.25)\end{array}$ \\
\hline $4001-5000$ & $\begin{array}{l}19.18 \\
(0.58)\end{array}$ & $\begin{array}{l}33.81 \\
(0.38)\end{array}$ & $\begin{array}{l}20.34 \\
(1.85)\end{array}$ & $\begin{array}{l}57.63 \\
(2.28)\end{array}$ & $\begin{array}{l}22.46 \\
(1.92)\end{array}$ & $\begin{array}{l}91.14 \\
(1.43)\end{array}$ \\
\hline$>5000$ & $\begin{array}{l}17.28 \\
(0.49)\end{array}$ & $\begin{array}{l}37.42 \\
(0.31)\end{array}$ & $\begin{array}{l}16.74 \\
(1.44)\end{array}$ & $\begin{array}{l}75.78 \\
(1.66)\end{array}$ & $\begin{array}{l}22.57 \\
(1.62)\end{array}$ & $\begin{array}{l}90.22 \\
(1.13)\end{array}$ \\
\hline
\end{tabular}

Notes: (1) Standard Errors are in parentheses. (2) The data Eor these calculations came from the Public-Use Data File documented in Woodbury et al. (1987). (3) Sample sizes for the income classes in the Control Group and the Claimant Experiment can be seen in Table 10. 
Table 13

The Frequency of Recall in Subsamples of the Missouri Data

(1) Total sample size

(2) Individuals recalled by

their previous employer

Number

As a percentage of total sample

(3) Individuals using state

employment service (ES)

Number

As a percentage of zotal sample

(4) Those using ES who are recalled

by their previous employer

Number

As a percentage of those using ES

(5) Those using ES who have short

unemployment spells (less

than or equal to 11 weeks)

Number

As a percentage of those using ES

(6) Those using ES, with short spel1s, who are recalled

Number

99

As a percentage of those using ES with short spells $+8$

Note: The data for these calculations came from the data set constructed by Corson and Nicholson and documented in Corson and Hilton (1982). The data were extensively recoded as indicated in Katz and Meyer (1988). 
Figure 1

\section{Income}

(\$)

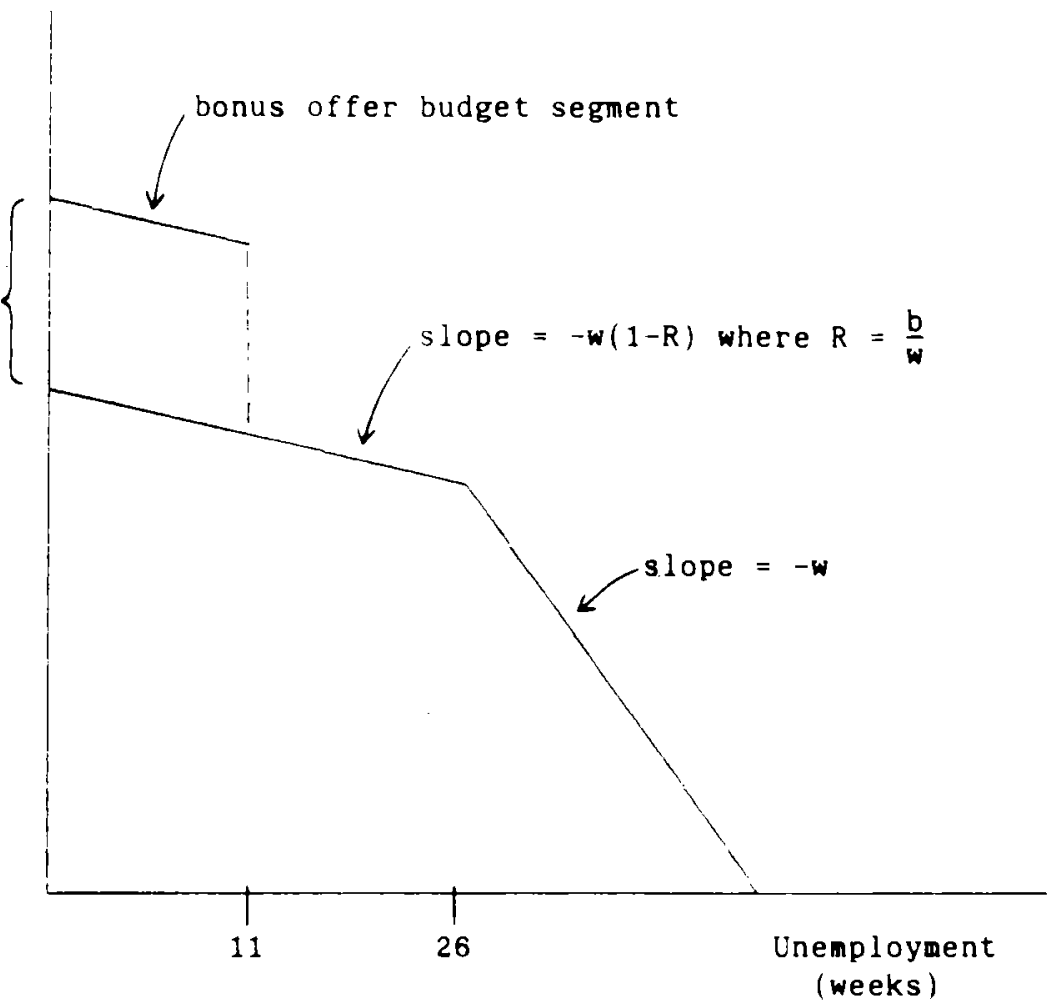




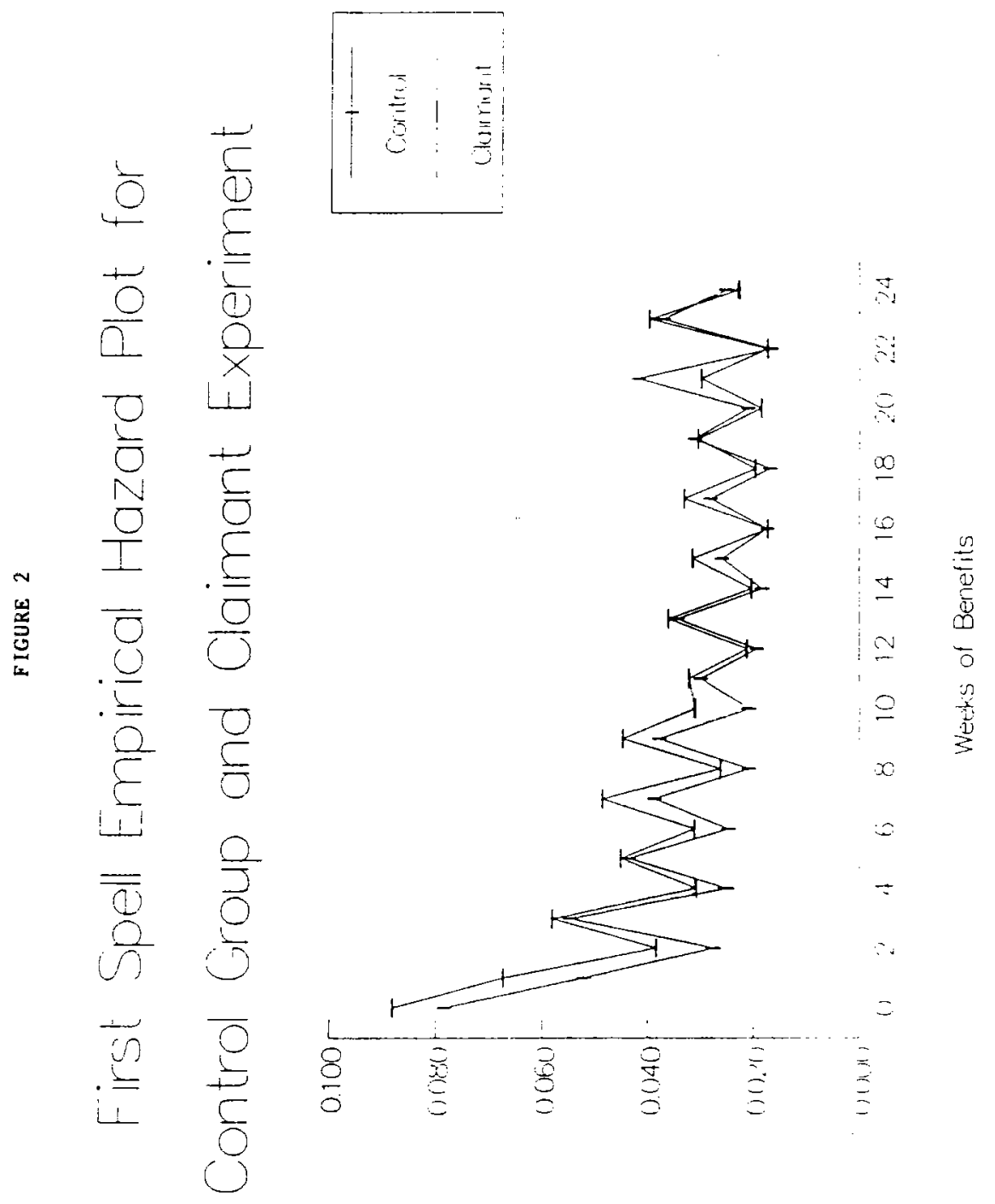




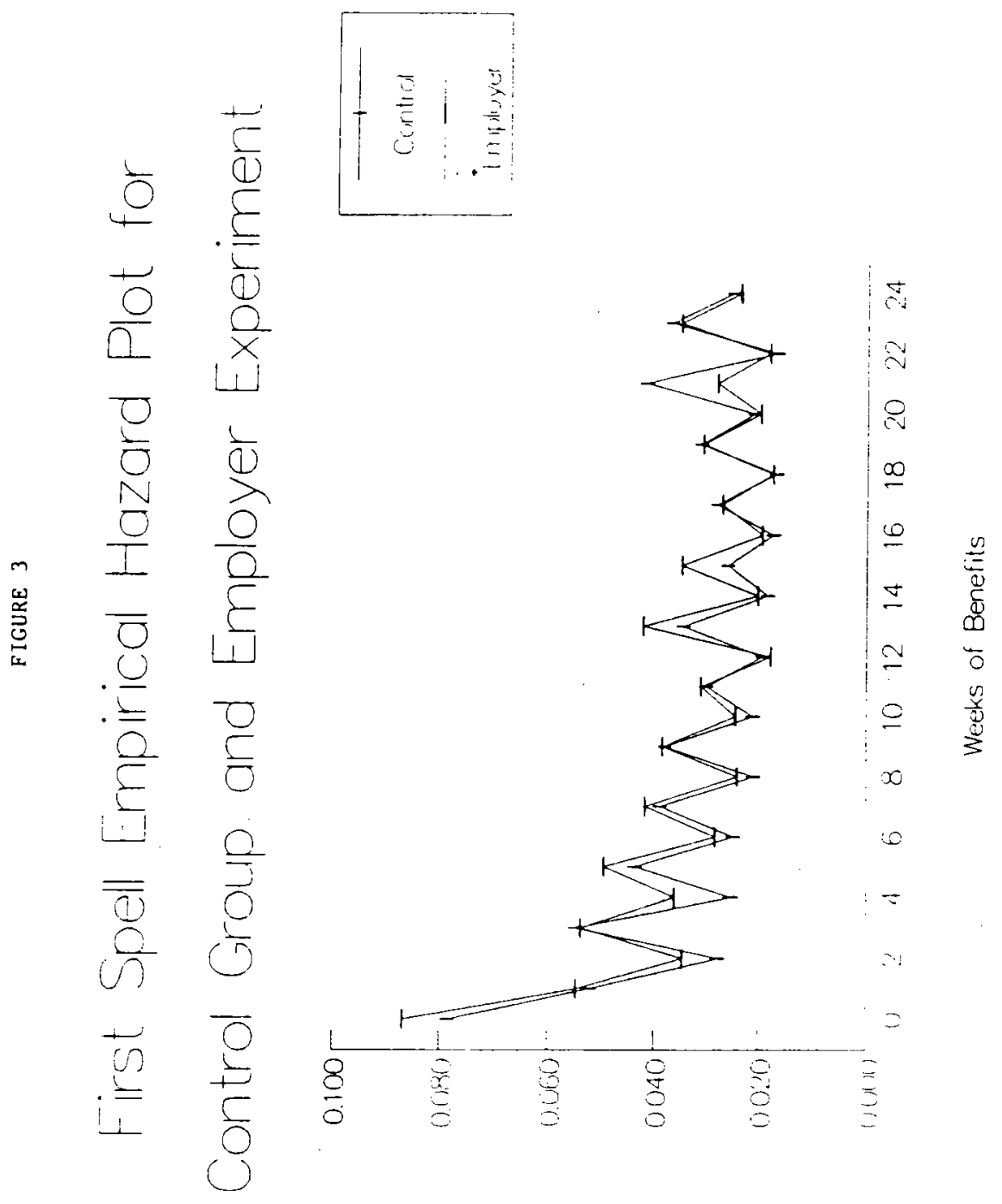

PADEOH 


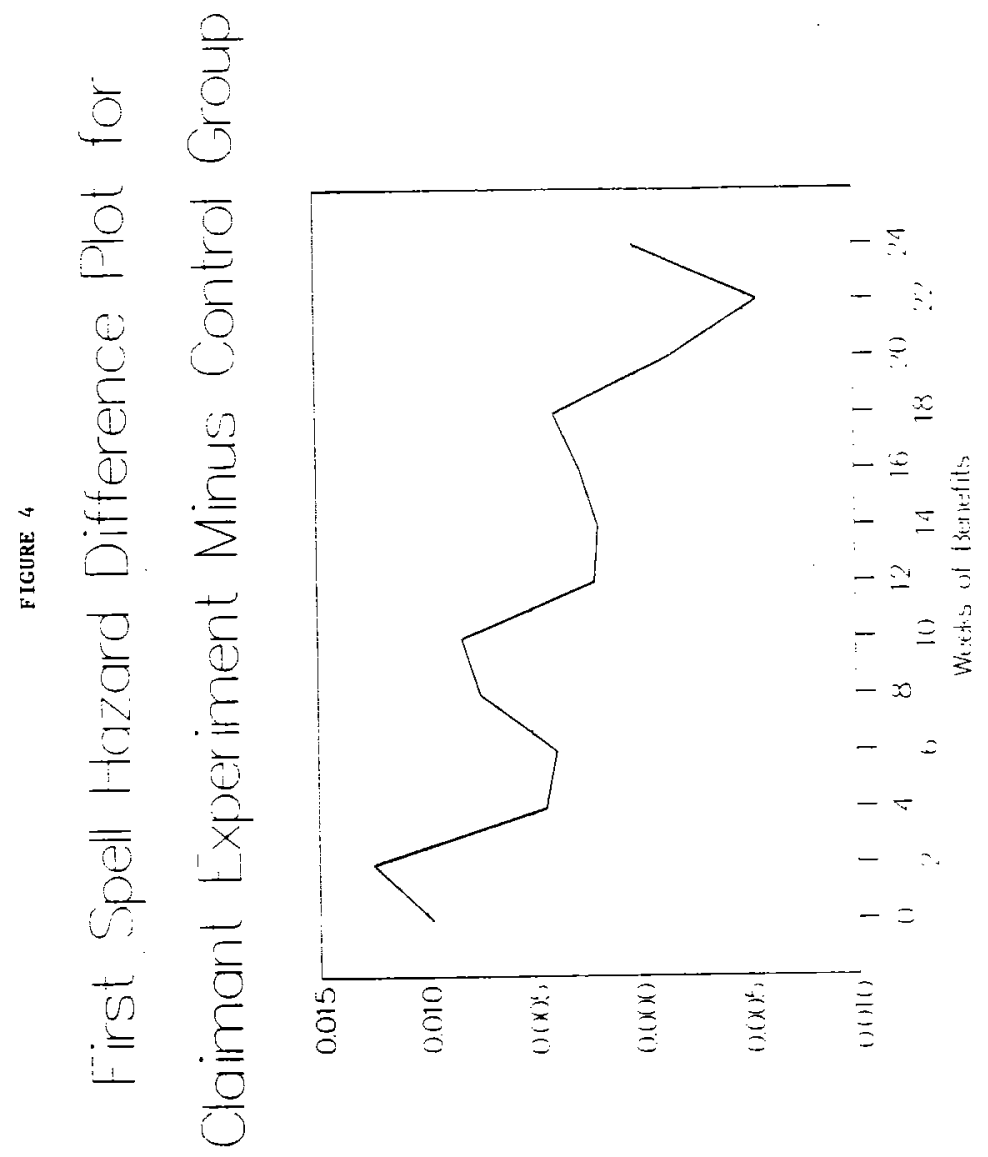

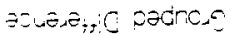




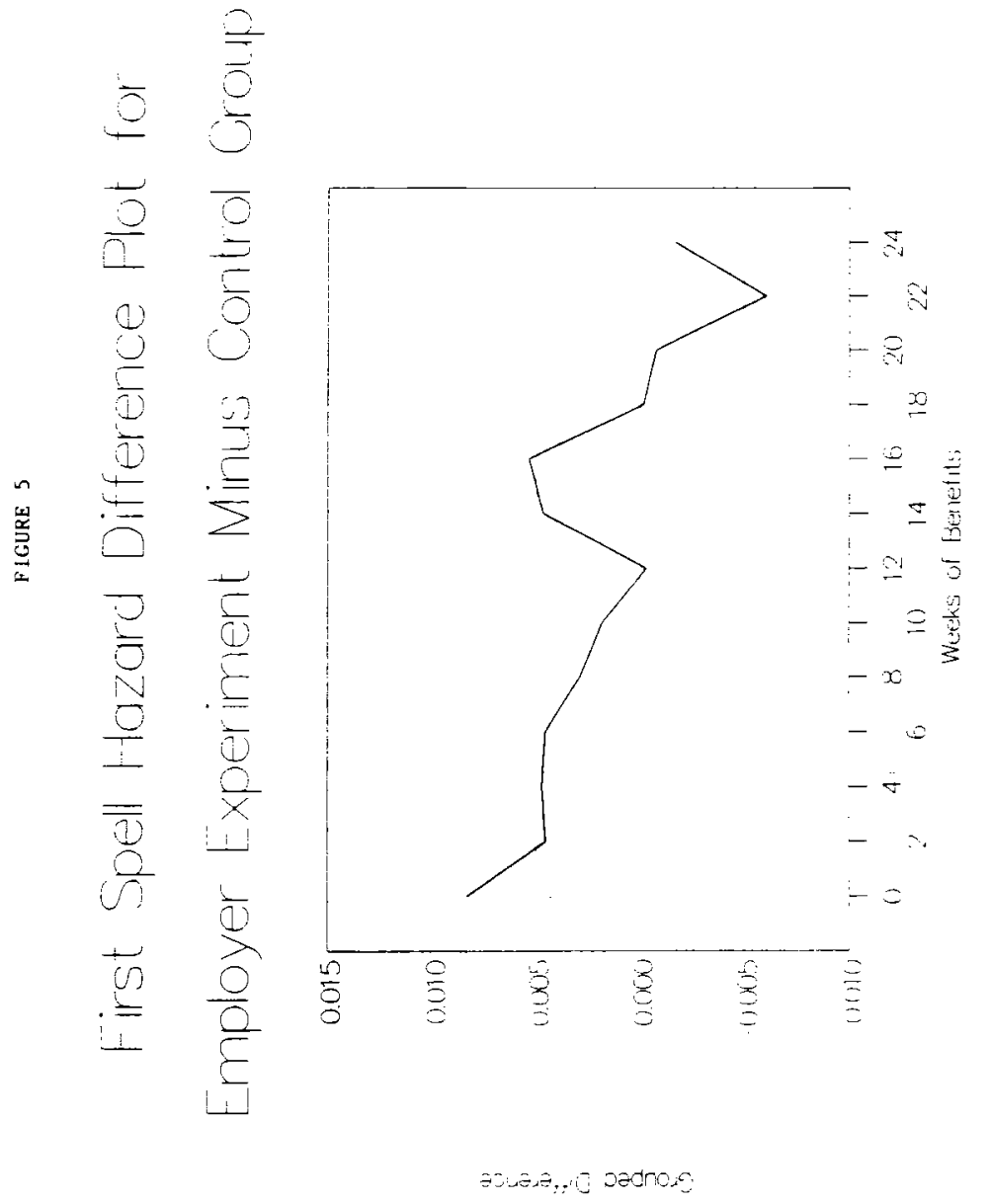

